\title{
COPD: current therapeutic interventions and future approaches
}

\author{
P.J. Barnes* and R.A. Stockley $\#$
}

ABSTRACT: Although long-acting bronchodilators have been an important advance for the management of chronic obstructive pulmonary disease (COPD), these drugs do not deal with the underlying inflammatory process. No currently available treatments reduce the progression of COPD or suppress the inflammation in small airways and lung parenchyma. Several new treatments that target the inflammatory process are now in clinical development. Some therapies, such as chemokine antagonists, are directed against the influx of inflammatory cells into the airways and lung parenchyma that occurs in COPD, whereas others target inflammatory cytokines such as tumour necrosis factor- $\alpha$.

Broad spectrum anti-inflammatory drugs are now in phase III development for COPD, and include phosphodiesterase-4 inhibitors. Other drugs that inhibit cell signalling include inhibitors of p38 mitogen-activated protein kinase, nuclear factor-кB and phosphoinositide-3 kinase- $\gamma$. More specific approaches are to give antioxidants, inhibitors of inducible nitric oxide synthase and leukotriene $\mathrm{B}_{4}$ antagonists. Other treatments have the potential to combat mucus hypersecretion, and there is also a search for serine proteinase and matrix metalloproteinase inhibitors to prevent lung destruction and the development of emphysema.

More research is needed to understand the cellular and molecular mechanisms of chronic obstructive pulmonary disease and to develop biomarkers and monitoring techniques to aid the development of new therapies.

\section{KEYWORDS: Chronic obstructive pulmonary disease}

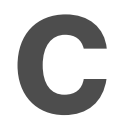
urrent therapy for chronic obstructive pulmonary disease (COPD) has improved the management of this difficult disease, but there is still a pressing need for new therapeutic approaches, particularly in reducing the progression and mortality of this disease. COPD has now become a much greater drain on health resources than asthma, and exceeds the healthcare spending on asthma by some three-fold in industrialised countries. As the prevalence of COPD is predicted to increase throughout the world over the next 20 yrs these costs will escalate further. There is no doubt that the management of COPD has improved considerably with the introduction of more effective treatments and the use of nonpharmacological interventions, such as pulmonary rehabilitation and noninvasive ventilation (NIV) [1, 2].

There is a pressing need for the development of new therapies for COPD, particularly as no existing treatment has been shown to reduce disease progression. New therapies for COPD may arise from improvements in existing classes of drug (for example, longer acting $\beta_{2}$-agonists and anticholinergics) or from the development of novel therapies based on a better understanding of the underlying disease process. There have been important advances in the current understanding of the cellular and molecular biology of COPD and this has been reviewed previously [3]. There are several new therapies now in development for COPD, which are targeted on the chronic inflammatory process (fig. 1) [4, 5]. Several of these therapies are discussed in this review. There is clearly a need for more research into the basic mechanisms of COPD, and, while the inflammatory process is now much better understood, it is not yet certain whether suppression of inflammation will stabilise COPD.

It has become clear that the inflammatory process increases in intensity as COPD progresses [6] and does not "burn out" as with many other chronic inflammatory diseases [7]. There is a complex remodelling process in the peripheral lung,

\section{AFFILIATIONS}

*National Heart and Lung Institute, Imperial College, London, and \#Dept of Medicine, Queen Elizabeth Hospital, Birmingham, UK.

\section{CORRESPONDENCE}

P.J. Barnes

National Heart and Lung Institute Imperial College School of Medicine Dovehouse St London SW3 6LY UK

Fax: 442073515675

E-mail: p.j.barnes@imperial.ac.uk

Received:

December 072004

Accepted:

January 052005 


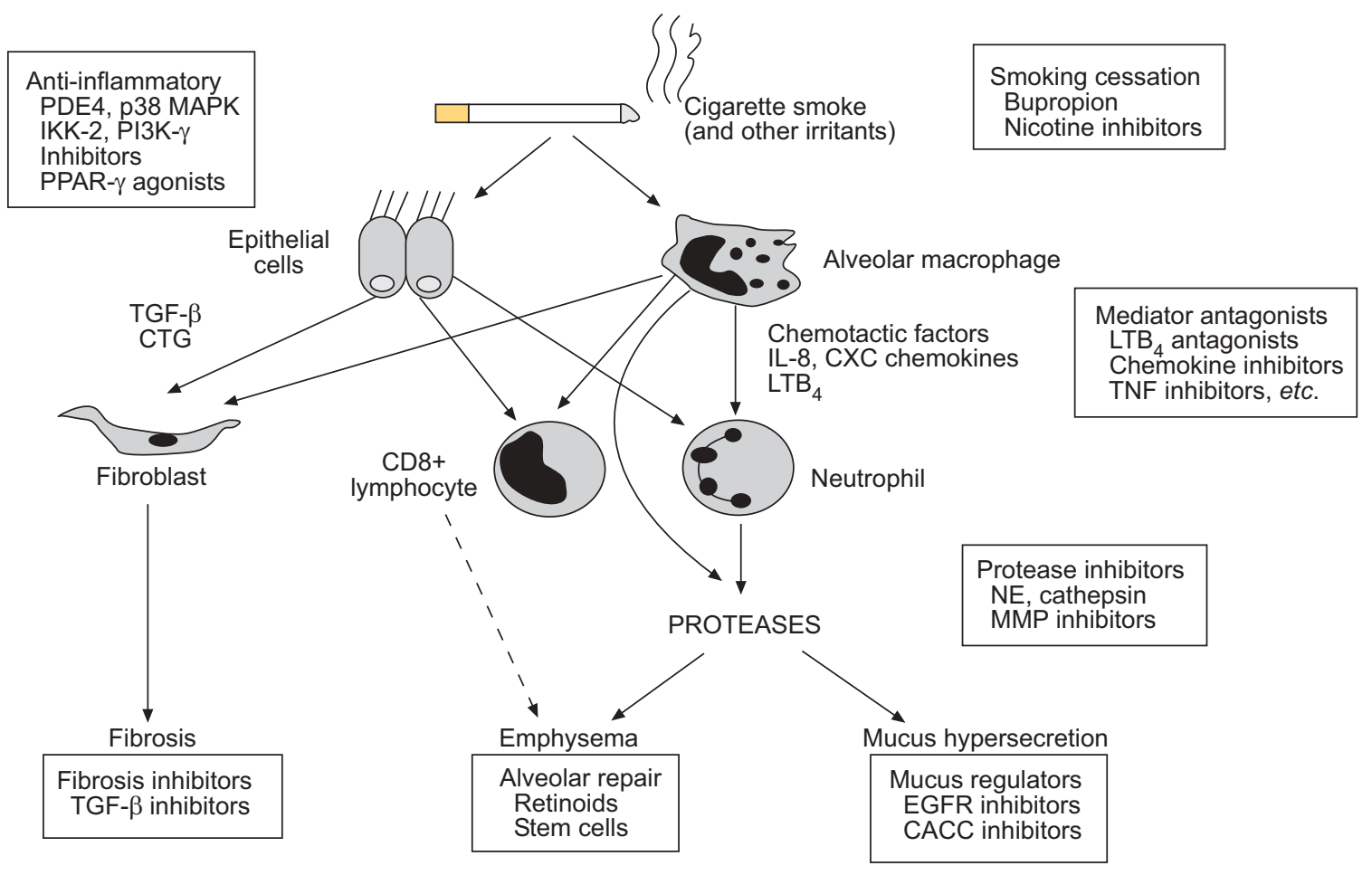

FIGURE 1. Targets for chronic obstructive pulmonary disease therapy based on the current understanding of the inflammatory mechanisms. Cigarette smoke (and other irritants) activate macrophages in the respiratory tract that release neutrophil chemotactic factors, including interleukin (IL)- 8 and leukotriene $B_{4}$ (LTB 4 ). These cells then release proteases that break down connective tissue in the lung parenchyma (resulting in emphysema), and also stimulate mucus hypersecretion. Cytotoxic T-cells (CD8+) may also be involved in alveolar wall destruction. This inflammatory process may be inhibited at several stages. PDE: phosphodiesterase inhibitor; MAPK: mitogen-activated protein kinase; IKK: inhibitors of nuclear factor-kB kinase; PPAR: peroxisome proliferator-activated receptors; TGF: transforming growth factor; CTG: connective tissue growth factor; TNF: tumour necrosis factor; NE: neutrophil elastase; MMP: matrix metalloproteinase; EGFR: epidermal growth factor receptor; CACC: calcium-activated chloride channel.

resulting in parenchymal destruction (emphysema) and fibrosis of small airways (chronic obstructive bronchiolitis). It is presumed that the inflammatory process leads to these structural changes and, hence, is the scientific rationale for the development of anti-inflammatory therapies. However, it is possible that the structural changes may evolve independently from the inflammation and that dysregulated repair mechanisms may even drive the inflammatory process, a concept that is now emerging in fibrotic lung diseases [8].

There are several reasons why drug development in COPD is difficult. Animal models of COPD for early drug testing are not very satisfactory $[9,10]$. There are uncertainties about how to test drugs for COPD, which may require long-term studies (over 3 yrs) in relatively large numbers of patients. Many patients with COPD may have comorbidities, such as ischaemic heart disease and diabetes, which may exclude them from clinical trials of new therapies. There is little information about surrogate markers (for example biomarkers in blood, sputum or breath) to monitor the short-term efficacy and predict the long-term potential of new treatments.

\section{SMOKING CESSATION}

Cigarette smoking is the major cause of COPD in the world and smoking cessation is the only therapeutic intervention so far shown to reduce disease progression [11, 12]. Nicotine addiction/dependence is the major problem and treatment should be directed at dealing with this addictive state. At present, several forms of nicotine replacement therapy and some antidepressant drugs are used, but the efficacy of these therapies is low and only a minority of patients maintain abstinence for 6 months [13]. The most effective therapy available is the atypical antidepressant bupropion and a short course is an effective adjunct for smoking cessation in patients with COPD [14, 15]. However, the relatively poor long-term quit rate $(16 \%$ at 6 months) indicates that more effective approaches are needed [16].

\section{New therapies for nicotine addiction}

Several new classes of non-nicotinic drugs for smoking cessation are now in development, based on altering neurotransmitter systems in the nucleus accumbens that are involved in "reward". These drugs include antagonists of metabotropic glutamate, dopamine $D_{3}$, cannabinoid $C_{1}$ receptors, gamma-aminobutyric acid $\left(\mathrm{GABA}_{\mathrm{B}}\right)$ and corticotrophin-releasing factor agonists $[17,18]$. These drugs have been tested in various animal models, but their effects do not usually outlast the period of administration, so they do not have good prospects for long-term efficacy. The $\mathrm{CB}_{1}$ antagonist rimonabant is currently in phase III trials for smoking cessation.

The partial nicotine agonists that target the $\alpha_{4} \beta_{2}$ nicotinic acetylcholine receptor, such as varenicline, appear to be 
promising in clinical trials $[19,20]$. Another approach which may have longer term benefits is the development of a vaccine against nicotine [21]. The vaccine is designed to stimulate the production of antibodies that bind nicotine so that it cannot enter the brain. Clinical trials with a nicotine conjugated vaccine (nicVax) are now underway.

\section{LONG-ACTING BRONCHODILATORS}

COPD guidelines now recommend the use of long-acting bronchodilators as the mainstay of COPD management. The introduction of the long-acting $\beta_{2}$-agonists formoterol and salmeterol and the anticholinergic tiotropium bromide have been important advances in the management of COPD [22, 23].

\section{Long-acting $\beta_{2}$-agonists}

Both formoterol and salmeterol are effective bronchodilators in COPD patients and are more effective than short-acting bronchodilators and theophylline [24, 25]. These drugs improve forced expiratory volume in one second (FEV1), reduce symptoms and use of rescue, short-acting bronchodilators and in some trials improve exercise capacity and health status. In some studies, long-acting $\beta$-agonists (LABAs) reduce exacerbation frequency, although this has been found in post hoc analyses. Both LABAs appear to have comparable efficacy, but no controlled comparative trials have been published so far, although LABAs have an add-on effect to short-acting anticholinergics [26]. Tolerance in the long-term use of LABAs does not appear to be a problem in clinical practice. Concerns have been raised about the side-effects of LABAs, particularly cardiac dysrhythmias, in susceptible elderly populations but salmeterol $50 \mu \mathrm{g} b . d$. and formoterol $12 \mu \mathrm{g} b . d$. are effective and safe in treating patients with COPD [27]. Higher doses may cause more adverse effects, although serious adverse events are very uncommon. Formoterol has been used as an acute relieving bronchodilator in asthma as it is possible to increase the dose without prolonged side-effects [28]. There is evidence that formoterol may also be used as a rescue inhaler in COPD without significant unwanted effects [29]. Whether high dose formoterol can be used to treat acute exacerbations of COPD as an alternative to nebulised short-acting $\beta_{2}$-agonists has not yet been established, although a single high dose of formoterol is well tolerated [30].

There is considerable interest in the potential nonbronchodilator actions of LABAs in COPD [31]; however, there are no reports of the direct effects of LABAs on airway inflammation in COPD patients. In a study of asthma patients salmeterol appears to decrease neutrophil numbers in bronchial biopsies, indicating a possible effect on neutrophil chemotaxis [32]. Indeed, salmeterol treatment is associated with a reduction in interleukin(IL)-8 concentrations in bronchoalveolar lavage fluid (BALF) of asthmatic patients [33]. Salmeterol reduces neutrophilic inflammation induced by inhaled endotoxin in mice [34]. LABAs inhibit neutrophil respiratory burst [35] and reduce adhesion of neutrophils to airway epithelial cells through inhibition of the expression of CD11b/CD18 on the neutrophil surface [36]. LABAs also reduce airway microvascular leakage, which is increased in COPD [37-39], all of which suggest an anti-inflammatory profile. There is also an increase in ciliary beating through an effect on epithelial $\beta_{2^{-}}$ receptors, which may increase mucociliary clearance $[40,41]$.
Of further interest, LABAs reduce adherence of bacteria, such as Haemophilus influenzae and Pseudomonas, to airway epithelial cells [42, 43]; this might reduce bacterial exacerbations in COPD. It is possible that these nonbronchodilator effects of LABAs become tolerant and this is more likely than downregulation of the bronchodilator effect of $\beta_{2}$-receptors on inflammatory cells [44]. It is possible that the addition of a corticosteroid may prevent this down-regulation of $\beta_{2}$-receptors and thus enhance the efficacy of LABAs in COPD patients [45].

New advances include longer acting $\beta_{2}$-agonists that are suitable for once daily administration, such as QAB 149, and these are now in clinical development.

\section{Tiotropium bromide}

Tiotropium bromide is a long-acting anticholinergic drug that slowly dissociates from muscarinic $(\mathrm{M})_{1}$ and $\mathrm{M}_{3}$ receptors and more rapidly from $\mathrm{M}_{2}$ receptors [46,47]. It is given as a once daily dry powder inhalation, but it has a longer duration than $24 \mathrm{~h}$ so may remain effective even if it is not taken each day. Tiotropium bromide is well tolerated and the only significant side-effect is dryness of the mouth which occurs in $10-15 \%$ of patients, but is not troublesome enough to cause discontinuation of therapy [48]. Placebo-controlled studies over 12 months have shown an increase in FEV1, decreased dyspnoea, improved exercise tolerance and improved health status [49]. Tiotropium reduces residual volume and improves inspiratory capacity [50], providing a sustained reduction in hyperinflation, resulting in a $\sim 20 \%$ increase in exercise endurance [51]. There is some evidence that tiotropium bromide also reduces COPD exacerbations and hospitalisations [49, 52]. The mechanism whereby tiotropium reduces exacerbations is currently unknown. Tiotropium taken once daily is more effective than the standard dose of ipratropium bromide q.i.d. in every clinical parameter [52]. There are few comparative studies with LABAs, but in one study it was suggested that tiotropium was more effective than salmeterol (b.i.d.). However, this was based on a lack of significance of the difference of salmeterol from placebo in one part of the study, rather than a difference between the two active agents $[53,54]$. Comparative studies are needed, and, in particular, studies should now be conducted that explore what factors predict which patient may respond to one class of bronchodilator better than another.

Other long-acting anticholinergics are currently in development, including the old anticholinergic glycopyrrolate, which had similar pharmacological properties to tiotropium bromide $[55,56]$. Novel long-acting anticholinergics, such as LAS34273 are also in development [57].

There is some evidence that anticholinergic drugs have effects on inflammatory cells, including neutrophils, macrophages and T-lymphocytes, raising the possibility that anticholinergics might also have some anti-inflammatory effects [58]. Furthermore, there is increasing evidence that acetylcholine may be released from non-neuronal cells, such as epithelial cells and macrophages, which express the enzyme choline acetyltransferase. This enzyme synthesises acetylcholine, the high-affinity choline transporter and vesicular acetylcholine transporter $[59,60]$. It is likely that inflammatory mediators, 
such as tumour necrosis factor (TNF)- $\alpha$, increase the expression of these proteins, resulting in increased local acetylcholine production. This may account for the surprising benefit of long-acting anticholinergic drugs and their beneficial effects on exacerbations, when inflammation increases.

\section{Combination inhalers}

There is clear evidence for additive effects of short-acting anticholinergics with $\beta_{2}$-agonists, leading to the introduction of combination inhalers [61]. There is emerging evidence that LABAs and tiotropium may also have additive effects [62], suggesting that a combination of LABAs and tiotropium or other long-acting anticholinergics may be useful [63]. A once daily inhaler with a once daily $\beta_{2}$-agonist and anticholinergic would, therefore, be ideal.

\section{Theophylline}

Theophylline has been relegated to third-line therapy in COPD. Theophylline is still used as a bronchodilator, but its use has been superseded by inhaled anticholinergics and $\beta_{2^{-}}$ agonists $[1,2]$. Theophylline tends to be added to these inhaled bronchodilators in more severe patients and has been shown to give additional clinical improvement when added to a longacting $\beta_{2}$-agonist $[64,65]$. As in asthma, patients with severe COPD deteriorate when theophylline is withdrawn from their treatment regime [66]. A theoretical advantage of theophylline is that it its systemic administration may have effects on small airways that are not targeted by the inhaled route, resulting in reduction of hyperinflation and, thus, a reduction in dyspnoea [67]. However, it does not appear to be of value in treatment of acute exacerbations of COPD [68]. When theophylline was first introduced as an asthma therapy it was used as a bronchodilator and early dose-response studies showed an increasing acute bronchodilator response above plasma concentrations of $10 \mathrm{mg} \cdot \mathrm{L}^{-1}(55 \mu \mathrm{M})$. The upper recommended plasma concentration was set at $20 \mathrm{mg} \cdot \mathrm{L}^{-1}$ due to unacceptable side-effects above this level. The therapeutic range for plasma concentrations was, therefore, established at $10-20 \mathrm{mg} \cdot \mathrm{L}^{-1}$ and doses were adjusted in individual patients to achieve this. Theophylline directly relaxes human airways smooth muscle in vitro and, like $\beta_{2}$-agonists, acts as a functional antagonist, preventing and reversing the effects of all bronchoconstrictor agonists. The molecular mechanism of bronchodilatation is probably explained by phosphodiesterase (PDE) inhibition, resulting in an increase in cyclic adenosine $3^{\prime}, 5^{\prime}$-monophosphate by inhibition of PDE3 and PDE4, and in cyclic guanosine $3^{\prime}, 5^{\prime}-$ monophosphate by inhibition of PDE5 [69].

There is increasing evidence that theophylline has antiinflammatory effects in asthma and COPD [70]. In patients with COPD, low doses of theophylline reduce the total number and proportion of neutrophils in induced sputum, the concentration of interleukin (IL)-8, and myeloperoxidase and neutrophil chemotactic responses, suggesting that it may have beneficial anti-inflammatory effects [71]. In another placebocontrolled study in COPD patients a significant reduction in myeloperoxidase and neutrophil elastase occurred after 4 weeks of treatment with theophylline [72]. This is in sharp contrast to the failure of high doses of inhaled corticosteroids to demonstrate such an effect in a similar population of patients [73-75]. These anti-inflammatory effects are seen at concentrations that are $<10 \mathrm{mg} \cdot \mathrm{L}^{-1}$, which is below the dose where clinically useful bronchodilatation is evident.

Until recently it has been difficult to find a significant molecular mechanism that occurs at these low concentrations. Several molecular mechanisms for the anti-inflammatory actions of theophylline have been proposed, particularly its inhibitory effects on PDEs [70]. While this may account for the bronchodilator action of theophylline, it is unlikely to account for the anti-inflammatory actions of theophylline, which occur at plasma concentrations of $<10 \mathrm{mg} \cdot \mathrm{L}^{-1}$ [76]. Recently a novel mechanism of action has been proposed that is relevant to inflammation at low plasma concentrations. Theophylline activates histone deacetylases (HDAC), which are nuclear enzymes involved in the switching off of activated inflammatory genes, such as those encoding for cytokines [77]. This effect of theophylline is blocked by the nonselective HDAC inhibitor trichostatin A. There appears to be a relatively direct activation of HDAC since the effect of theophylline is observed in nuclear extracts of activated inflammatory genes, but the precise molecular mechanism of action is not yet certain. However, the effects of theophylline on HDAC are not explained by either PDE inhibition or adenosine antagonism. The effect on HDAC activity appears to be amplified under conditions of oxidative stress. This is partly due to the fact that baseline HDAC activity is low, but may also arise because theophylline interferes with a signal transduction pathway(s) activated by oxidative stress. In COPD alveolar macrophages there is a marked reduction in HDAC activity that is restored to above normal by low concentrations of theophylline [78].

The novel action of theophylline predicts that theophylline alone has a relatively weak anti-inflammatory action, whereas it will be potentiated by the anti-inflammatory effect of corticosteroids. The combination of low concentrations of theophylline $\left(10^{-5} \mathrm{M}\right)$ and low concentrations of dexamethasone $\left(10^{-10} \mathrm{M}\right)$ increase the repression of inflammatory cytokine release in both macrophages and epithelial cells, whereas alone neither had an effect [79]. Theophylline, through direct activation of HDACs, is able to reverse the effect of oxidative stress and cigarette smoke extract and, thus, restore corticosteroid responsiveness in cell lines and alveolar macrophages from smokers and COPD patients [78, 79]. This effect of theophylline is completely reversed by trichostatin $\mathrm{A}$, a nonselective inhibitor of HDACs, thus, confirming that the enhancement of corticosteroid responsiveness by theophylline is mediated via HDAC. This suggests that theophylline has the potential to "unlock" the resistance to corticosteroids that is seen in patients with COPD. Clinical studies to determine whether theophylline allows corticosteroids to exert an antiinflammatory effect in COPD patients are now in progress.

Although theophylline has recently been used much less in industrialised countries, the recent appreciation of its antiinflammatory effects at low doses has rekindled interest in this drug. There is a particular reason to explore this drug further in COPD patients as corticosteroids are ineffective as an antiinflammatory treatment and PDE4 inhibitors have relatively frequent side-effects. The fact that anti-inflammatory effects occur at low plasma concentrations $\left(5-10 \mathrm{mg} \cdot \mathrm{L}^{-1}\right)$ and, hence, largely avoid the dose-dependent side-effects, makes them an attractive treatment. These agents are the only currently 
available therapy for COPD patients that are anti-inflammatory. Furthermore, low doses of theophylline do not have any significant problems of drug interactions that occur with the higher doses used previously. They are inexpensive and do not require by plasma concentration monitoring that made the previous clinical use of theophylline cumbersome in general practice. If theophylline is able to restore corticosteroid sensitivity in COPD patients, as have been demonstrated in cells in vitro and animals in vivo, then the use of low-dose theophylline combined with a low dose of inhaled or even oral steroids may be effective as an anti-inflammatory therapy and hence reduce the progression of the disease. A particular attraction of this approach is that theophylline becomes more effective as oxidative stress increases, making it ideal for treating all stages of the disease without having to change the dose.

There is the potential for designing novel theophylline-like molecules that mimic HDAC activation, but avoid PDE inhibition or adenosine receptor antagonism. Such agents would, therefore, be free of side-effects that have previously limited clinical use of theophylline. There may also be other novel structures that mimic the effect of theophylline and could be identified by high throughput screening using HDAC activation as a read-out. This could lead to the development of novel oral anti-inflammatory drugs that may be used alone or in combination with corticosteroids in the treatment of COPD. Such novel agents would have the potential for unlocking the steroid resistance that limits the clinical usefulness of corticosteroids in this disease at present.

\section{CORTICOSTEROIDS}

The place of corticosteroids in COPD therapy remains uncertain. High doses of systemic steroids (oral or intravenous) provide modest benefit in reducing hospital stay and the time until the next exacerbation and are, therefore, routinely used in the management of hospital admissions [80]. They are also useful in reducing re-admission rate when given to outpatients after emergency treatment [81]. However, in general, corticosteroids should not be administered for $>2$ weeks because of adverse effects.

High-dose inhaled corticosteroids have minimal effects on lung function when given alone but there is evidence that they reduce exacerbations in patients with severe disease [82, 83]. They are now recommended as an add-on therapy in patients with severe and very severe COPD (FEV1 $<50 \%$ predicted) who have $\geqslant 2$ or more exacerbations per year. Four large controlled trials of 3-yr duration have demonstrated no significant effect of inhaled corticosteroids on the loss of lung function that occurs in COPD [84]. This is likely to reflect the fact that corticosteroids do not suppress the appropriate inflammation in COPD lungs (in marked contrast to their potent anti-inflammatory action and clinical efficacy in asthma). However, it is apparent that a proportion of patients with COPD appear to show a response to inhaled corticosteroids and these tend to be the patients with a greater bronchodilator response, higher eosinophil counts in sputum and higher exhaled nitric oxide (NO) concentrations [85, 86]. It is likely that this subset of patients also have concomitant asthma which needs to be treated.

\section{Corticosteroid resistance}

Neither inhaled nor oral corticosteroids suppress the inflammation in COPD [73-75, 87]. Alveolar macrophages from COPD patients appear to be steroid-resistant [88]. There may be an active resistance to corticosteroids due to an inhibitory effect of cigarette smoke on the HDACs required for corticosteroids to switch off inflammatory genes [89, 90]. Based on this concept, therapeutic strategies that unlock the molecular mechanism of resistance might be possible, as drugs that increase HDAC activity may re-sensitise cells to the effects of corticosteroids. As discussed previously, low concentrations of theophylline increase the activation of HDACs and increase the responsiveness to corticosteroids, at least in vitro [77, 78]. Since the mechanism for the reduction of HDAC activity in COPD may be mediated by oxidative stress and the formation of peroxynitrite $[90,91]$, it is possible that antioxidants and inhibitors of NO synthesis may also restore steroid sensitivity in COPD by similar mechanisms.

\section{Combination inhalers}

Combination inhalers of a steroid and a LABAs appear to be more effective than either drug alone on FEV1, symptom control, health status and exacerbations [92-94]. For some of the outcome measures there may even be synergistic interactions. Indeed there may be molecular interactions between $\beta_{2}$-agonists and corticosteroids that lead to enhanced effects, as described in asthma (fig. 2) [95]. Combination inhalers may have a useful role in COPD and may improve compliance and efficacy when both an inhaled corticosteroid and LABAs are indicated [96, 97].

\section{OTHER THERAPIES \\ Antibiotics}

There is good evidence that some exacerbations of COPD are caused by bacteria [98, 99], and it is likely that bacterial infection may complicate virus-initiated exacerbations. Antibiotic therapy is associated with more rapid recovery from exacerbations than placebo [100]. However, empirical antibiotics have a small effect [101], although they may be more effective in the patients with purulent sputum [102]. One of the problems is deciding which exacerbations are due to bacterial infection. There has been a search for clinically useful markers of bacterial infection, such as serum procalcitonin [103]. In reality, a simple observation of sputum purulence (colour) not only identified patients likely to have bacteria in their sputum [102], but also the size of the bacterial load [104]. Furthermore, resolution of an exacerbation occurs without antibiotics if the sputum is mucoid at presentation [102]. The role of exacerbations in the natural history of COPD has been controversial, but there is some evidence that more frequent exacerbations increase the decline in lung function $[105,106]$. However, it is uncertain whether antibiotic therapy might reduce this decline in lung function as it is difficult to devise trials now that the use of antibiotics is so prevalent in clinical practice.

\section{Anti-inflammatory effects of macrolides}

Macrolide antibiotics have anti-inflammatory effects in vitro, including inhibition of chemotaxis, inhibition of cytokine expression and inhibition of reactive oxygen species generation $[107,108]$, although the molecular mechanisms for these effects 


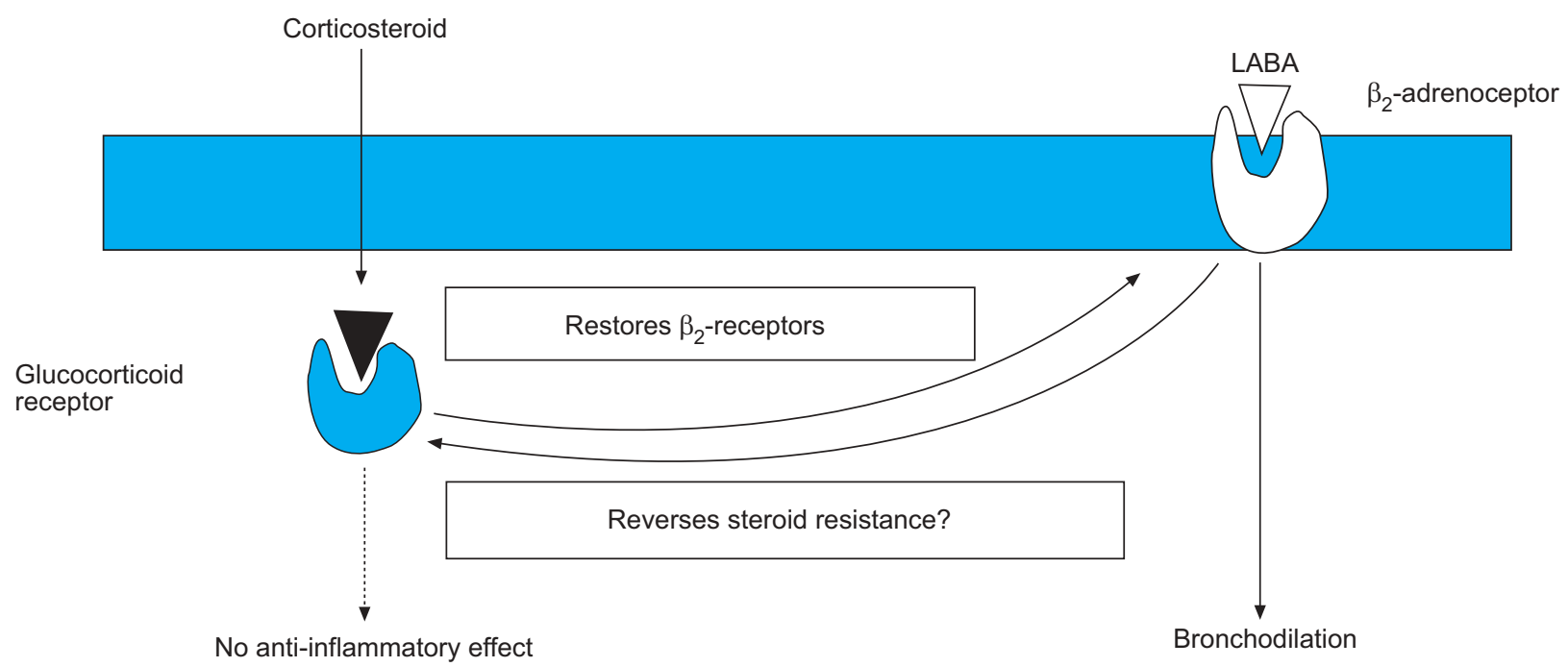

FIGURE 2. Combination therapy in chronic obstructive pulmonary disease. Long-acting $\beta_{2}$-agonists (LABAs) cause bronchodilatation, whereas corticosteroids have no significant anti-inflammatory effect when used alone. Corticosteroids increase expression of $\beta_{2}$-receptors and may restore reduced $\beta_{2}$-receptor numbers (possibly reduced by transforming growth factor- $\beta$ ). In turn, LABA may restore responsiveness to corticosteroids.

are not fully understood. Macrolides inhibit the activation of nuclear factor (NF)- $\kappa \mathrm{B}$ and activator protein-1 in epithelial cells and, interestingly, this effect is shared with nonbactericidal derivates, such as erythromycin-703 [109-111]. Low doses of macrolides are effective in the treatment of diffuse panbronchiolitis [112] and cystic fibrosis [113] and their benefit appears to be more than an anti-bacterial effect, suggesting that the anti-inflammatory action may be contributing. Long-term administration of macrolides may, therefore, have potential benefit in patients with COPD and clinical trials are currently underway.

\section{Bacterial colonisation}

The bacterial load in the sputum of COPD patients is associated with an increase in the concentrations of inflammatory markers, including IL-6, IL-8, neutrophil elastase and myeloperoxidase [104, 114]. Patients with high bacterial loads appear to have more frequent exacerbations [115] and may be associated with a more rapid decline in FEV1 [116]. The role of bacterial colonisation is uncertain, but may invoke a vicious circle whereby bacteria stimulate the inflammatory and immune response in the airways, resulting in airways damage. This response increases colonisation of the lower airways suggesting that strategies to reduce bacterial colonisation, such as long-term or cycling antibiotics, might reduce both exacerbations and disease progression.

\section{Oxygen therapy}

Long-term oxygen therapy (LTOT), where oxygen is delivered for $>12 \mathrm{~h} \cdot$ day $^{-1}$ increases survival and reduces morbidity of COPD with arterial hypoxaemia (arterial oxygen tension $\left(\mathrm{Pa}_{2} \mathrm{O}_{2}\right)$ $\leqslant 7.5 \mathrm{kPa})$ and $\mathrm{FEV} 1 \leqslant 50 \%$ pred $[117,118]$. It also reduces pulmonary vascular resistance in some, but not all, patients with pulmonary hypertension secondary to COPD [119].

\section{Oxygen delivery}

Oxygen is normally generated by a concentrator or supplied as liquid, which is suitable for ambulatory delivery [120, 121].
Supplementary oxygen does not improve the survival of patients without hypoxaemia, but it reduces exertional dyspnoea and increases the walking distance [122]. New delivery systems may prove to be simpler, more efficient and more cost-effective. The use of pulsed oxygen therapy, as has been used for NO delivery, reduces the gas volume 40-fold and markedly improves walking distance [123].

\section{Genetic factors}

Not all patients respond in the same way to hypoxia and may, therefore, have a differing propensity to develop secondary pulmonary hypertension. This may be determined to some extent by gene variations. For example, the DD variant of angiotensin-converting enzyme (ACE) I/D genotype may predispose to pulmonary hypertension at high altitude [124], and the BB genotype of endothelial NO synthase may increase the risk of pulmonary hypertension in COPD patients [125]. The transcription factor, hypoxia-inducible factor (HIF)- $1 \alpha$, regulates genes that are induced by hypoxia, such as endotheolin-1 and vascular endothelial growth factor, through prolyl hydroxylation of the transcription factor by several HIF hydroxylases [126]. Genetic polymorphisms of this transcription factor and its regulatory pathways may play a role in susceptibility to the effects of hypoxia.

\section{NONPHARMACOLOGICAL APPROACHES Pulmonary rehabilitation}

Several large-scale randomised studies have demonstrated that pulmonary rehabilitation improves exercise performance and health status in COPD patients [127]. The magnitude of these effects is often greater than those seen with most bronchodilators. Pulmonary rehabilitation also reduces the utilisation of healthcare resources [128, 129]. It remains uncertain whether pulmonary rehabilitation affects exacerbation frequency, disease progression or mortality. Some functional variables appear to predict a good response to pulmonary rehabilitation. Patients with reduced exercise capacity who experience less ventilatory limitation to exercise and more reduced respiratory 
and peripheral muscle strength appear more likely to improve, although the degree of improvement in individual patients is largely unpredictable [130]. Patients with severe airflow limitation appear to benefit as much as patients with milder disease. The active component of pulmonary rehabilitation is likely to be exercise training and peripheral muscle training [127]. There is still debate about the optimal length of training and number of sessions, but 6-month programmes appear to be better than shorter programmes and a 2-h session appears to be optimal. Most research is based on studies performed in a hospital setting, but home rehabilitation programmes may be possible, although less effective than hospital programmes [131]. Maintenance after the rehabilitation programme, including telephone calls, is beneficial and improves the long-term effect, although this has not been studied systematically [132].

An important area for future research would be to explore the interaction between pulmonary rehabilitation and current pharmacological therapies, particularly bronchodilators. Other therapies that are being evaluated include anabolic steroids, testosterone, insulin-like growth factor (IGF)-1, antiTNF or anti-IL-6, all of which may affect muscle function in COPD patients [133-135]. NIV in patients with severe ventilatory limitation appears to enhance the effects of exercise training $[136,137]$. In the future, better predictors of response are required and strategies to combine pulmonary rehabilitation with other therapies, especially treatments to enhance muscle strength, will need to be evaluated.

\section{Nutritional supplementation and treating systemic symptoms}

Systemic features of COPD are now recognised as an important feature of the disease [138, 139] and contribute significantly to decreased exercise capacity, decreased health status and increased mortality of COPD patients. The most extensively studied systemic features are cachexia and wasting of skeletal muscles. Several factors may contribute to these systemic effects, including inactivity, chronic hypoxia, medication and malnutrition. Loss of weight in COPD may arise from semi-starvation, cachexcia and sarcopenia, all of which may coexist. Semi-starvation is characterised by weight loss with relative preservation of lean body mass and is linked to anorexia. This may respond to nutritional supplementation and, as part of an integrated pulmonary rehabilitation programme, has been shown to increase weight in COPD patients [140]. The progestational agent megestrol acetate increases appetite and body weight in semi-starved COPD patients [141], but body changes do not increase lean tissue.

Cachexia is described as a loss of lean body mass with an impaired protein balance that may be secondary to systemic features of COPD. The finding of low IGF-1 and high IL-6 concentrations in the circulation of COPD patients suggest possible therapeutic approaches in the future if these factors drive or reflect the body mass changes [142]. Sarcopenia is a shift in body composition towards decreased lean body mass with preservation of fat mass. This may involve apoptosis of skeletal muscles $[143,144]$ and may be secondary to the release of cytokines, such as TNF- $\alpha$ and IL-1 $\beta$. Therapies that block TNF- $\alpha$ may, therefore, be able to reverse these effects on muscle metabolism. Skeletal muscle weakness and apoptosis in COPD has been linked to NF- $\kappa \mathrm{B}$ activation and activation of inducible NO synthase [145], providing several other therapeutic strategies that are discussed below.

Another systemic feature that may occur in COPD is osteoporosis, which may be mutifactorial, involving poor nutrition, the effects of high-dose inhaled and systemic corticosteroids and the effects of systemic inflammation on bone metabolism. The osteoporosis is closely related to loss of fat free mass, suggesting that it may be linked to systemic inflammation [146]. A final, often unrecognised, systemic component is normocytic anaemia, which may also reflect the systemic inflammation in severe patients.

\section{Noninvasive ventilation}

NIV has now been shown in several trials to be an effective treatment for ventilatory failure resulting from acute exacerbations of COPD [147]. It has been used in a variety of clinical settings with different ventilator modes and for exacerbations of differing severity. The most consistent finding is a reduction in the need for endotracheal intubation and invasive mechanical ventilation. This results in a reduced incidence of infections, length of intensive care and hospital stay, which leads to a significant reduction in healthcare costs [148]. There has been debate about whether patients with more severe exacerbations benefit, but a recent prospective study into such circumstances (mean arterial $\mathrm{pH}$ of 7.2) showed that NIV was as effective as intubation and mechanical ventilation with a shorter duration of intensive care unit stay [149].

Domiciliary NIV is also treatment for some patients with chronic stable hypercapnic COPD. NIV can correct abnormalities in gas exchange during sleep, improve exercise capacity and arterial blood gas tensions and increase health status, although most of the studies have involved relatively small numbers of patients and have been poorly controlled or too short in duration for firm conclusions to be drawn [150]. One of the larger studies adding NIV to LTOT showed improvement in symptoms and less frequent admissions to intensive care units over a 2-yr period, but overall the benefits were relatively minor [151]. Larger studies in stable hypercapnic COPD patients are needed with clearly defined outcome measures before this therapy can be recommended routinely.

\section{Lung volume reduction}

Lung volume reduction surgery improves lung function, exercise performance and health status in carefully selected patients. Originally supported by several case series this was later confirmed by clinical trials [152-154]. The large National Emphysema Treatment Trial had a period of 29 months followup and showed benefit in the patients with predominantly upper lobe disease and poor exercise performance [155]. A high risk group of patients with unacceptable mortality was defined by FEV1 $<20 \%$ predicted, non-upper lobe emphysema and a carbon monoxide diffusing capacity of $<20 \%$ predicted. All trials have reported more deaths in the surgical groups and this is a major limitation of the surgical approach. More recently various other approaches have been explored using bronchoscopic insertion of stents or gels to occlude the target lobe in order to achieve absorption collapse. Initial results are encouraging with improvement in lung function without significant adverse effects [156-158]. An alternative approach is to reduce expiratory airflow resistance by bypassing the 
flow-limiting smaller airway with new connections between emphysematous lung and cartilaginous larger airways, providing a surgical deflation of hyperinflated lung [159].

\section{Stem cells}

There is now a growing interest in the potential use of stem cells for the repair of damaged and destroyed lung tissues. Studies of lung injury indicate that type-II pneumocytes are able to repair areas of damage. Tracheal instillation of endotoxin results in a rapid mobilisation of bone marrow precursor cells (BMPCs) into the circulation in mice. BMPCs accumulate within the inflamed lung and differentiate into endothelial and epithelial cells. Suppression of BMPCs by sublethal irradiation before intrapulmonary lipopolysaccharide leads to the disruption of tissue structure and emphysemalike changes. Reconstitution of the bone marrow prevents these changes. This suggests that BMPCs are important and required for lung repair after inflammatory injury [160]. This raises the possibility of identifying bone marrow-derived cells that are potentially suitable for reversing the damaged alveoli in COPD patients. Extensive research is needed into the cell biology of lung stem cells and the factors that regulate differentiation of these cells into alveolar cells [161], although the therapeutic potential would be equally enormous.

\section{PHOSPHODIESTERASE-4 INHIBITORS Basic research}

There are now recognised to be over 11 families of PDE, which have differential expression and regulation [162]. There has been particular interest in PDE4, which hydolyses cyclic adenosine $5^{\prime}$-monophosphate and is the predominant PDE enzyme expressed in neutrophils, CD4+, CD8 ${ }^{+}$cells, monocytes and is also present in macrophages [163]. PDE4 is also present in airway smooth muscle and epithelial cells, indicating that PDE4 inhibitors could also have effects on structural cells (fig. 3). Thus, there is compelling scientific rationale for the use of PDE4 inhibitors in COPD, although their clinical development has been slow [164, 165]. Selective PDE4 inhibitors, such as rolipram, cilomilast and roflumilast, are

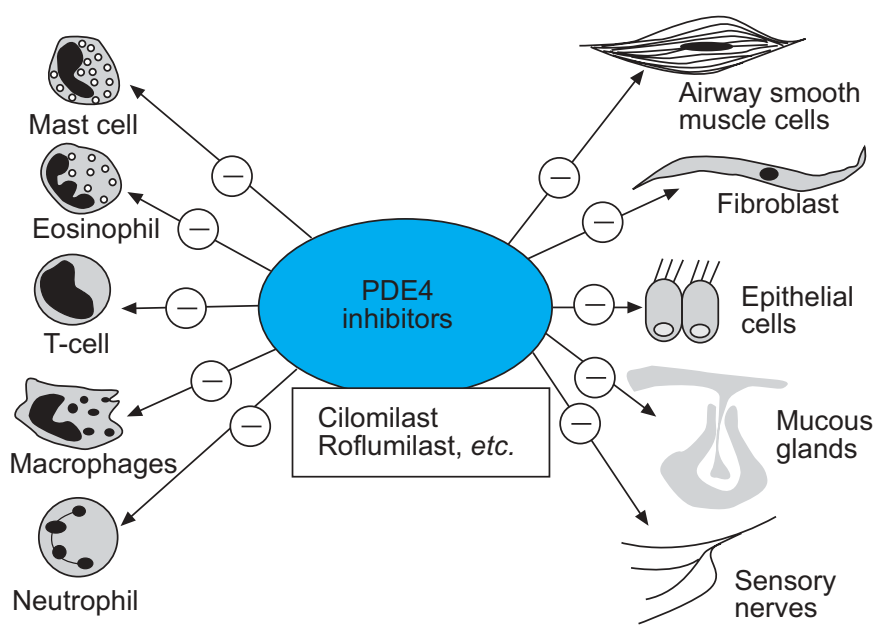

FIGURE 3. Phosphodiesterase-4 (PDE4) inhibitors have the potential to suppress inflammatory cells and structural cells in chronic obstructive pulmonary disease patients, giving a broad spectrum anti-inflammatory profile. active in several animal models of neutrophil inflammation, confirming their anti-inflammatory potential [166, 167].

\section{Clinical studies}

Published clinical studies with PDE4 inhibitors in COPD patients are limited. Cilomilast improved lung function in a 6week study in patients with moderate-to-severe COPD [168] and has some anti-inflammatory effects measurable in airway biopsies [169]. Roflumilast appears to be better tolerated at doses that significantly inhibit TNF- $\alpha$ release from peripheral blood monocytes [170]. Although PDE4 appears to be important in regulating airway smooth muscle tone in murine airways [171], PDE4 inhibitors do not appear to have any significant bronchodilator action in human subjects, despite the expression of this enzyme in human airway smooth muscle cells. Phase III studies in large numbers of patients are now in progress to determine whether PDE4 inhibitors reduce exacerbations and improve lung function and health status in COPD patients.

\section{Side-effects}

A major hurdle to the development of PDE4 inhibitors as drugs has been the frequency of adverse effects, including nausea, diarrhoea and headaches, which have led to the discontinuation of several drugs in early development. The mechanism(s) of these side-effects is now a major area of research so that strategies to reduce or avoid these doselimiting side-effects may be avoided. The side-effects are mechanism related so it may be necessary to make more selective inhibitors or deliver the drugs by inhalation to avoid them.

It now seems likely that vomiting is due to inhibition of a particular subtype of PDE4. Four human PDE4 isoenzymes have been identified and each has several splice variants [163]. This raises the possibility that subtype-selective inhibitors may be developed that could preserve the anti-inflammatory effect, while having less propensity to side-effects. PDE4D (one of four genes encoding the PDE4 family) appears to be of particular importance in nausea and vomiting and is expressed in the chemosensitive trigger zone in the brain stem [172]. In mice, deletion of the gene for PDE4D prevents a behavioural equivalent of emesis [173]. This isoenzyme appears to be less important in anti-inflammatory effects and targeted gene disruption studies in mice indicate that PDE4B is more important than PDE4D in inflammatory cells [174, 175]. PDE4B-selective inhibitors may, therefore, have a greater therapeutic to side-effect ratio and theoretically might be effective anti-inflammatory drugs. Cilomilast is selective for PDE4D and this explains its propensity to cause emesis, whereas roflumilast, which is nonselective for PDE4 isoenzymes, has a more favourable therapeutic ratio. Several other potent PDE4 inhibitors with a more favourable therapeutic ratio are now in clinical development for COPD.

Another approach is to give PDE4 inhibitors by inhalation; some have a low oral bioavailability and are retained in the lung, suggesting that they may be more suitable for inhaled delivery [176]. Other problems with PDE4 inhibitors include ischaemic colitis in animal models, although the mechanism remains unknown, and an increased susceptibility to Klebsiella pneumoniae infections, possibly related to decreased TNF- $\alpha$ 
production [177]. This latter problem could potentially be detrimental in COPD patients who often have chronic bacterial colonisation of the lower airways.

\section{Phosphodiesterase-7 inhibitors}

Due to the side-effects of PDE4 inhibitors, other PDE isoenzymes that are expressed in inflammatory cells have also been investigated. PDE7A, like PDE4, is a cyclic AMP-selective PDE and has a widespread distribution in relevant inflammatory cells, including neutrophils, T-cells, monocytes and macrophages [178]. The PDE7-selective inhibitor BRL 50481 has minimal inhibitory effects on monocytes, macrophages and CD8+ T-cells, but potentiates the anti-inflammatory effects of a PDE4 inhibitor on these cells, suggesting that combinations of PDE inhibitors may prove more effective in targeting causative mechanisms [179].

\section{MEDIATOR ANTAGONISTS}

Multiple mediators are involved in the inflammatory process in COPD, although they are defined less well than in asthma [180]. This raises the possibility that blocking individual mediators might have therapeutic potential, but as in asthma this has proved a disappointing approach so far because of the enormous redundancy in mediators.

\section{Lipid mediator inhibitors}

Lipid mediators that are increased in COPD include prostaglandin (PG) $\mathrm{E}_{2}, \mathrm{PGF}_{2 \alpha}$ and thromboxane [181]. Cysteinylleukotrienes (cys-LTs) are not increased in exhaled breath of COPD patients as they are in asthma $[181,182]$ and there is no scientific rationale for the use of cys-LT $\mathrm{LT}_{1}$-receptor antagonists, such as montelukast, in COPD patients.

\section{Leukotriene $\mathrm{B}_{4}$ inhibitors}

Most attention has focussed on leukotriene (LT) $B_{4}$ because of its property of attracting and activating neutrophils through interaction with the high-affinity receptor for $\mathrm{LTB}_{4}\left(\mathrm{BLT}_{1}\right)$ receptors on the cell surface. $\mathrm{LTB}_{4}$ instillation into human lungs causes an intense neutrophilic inflammation [183]. $\mathrm{LTB}_{4}$ concentrations are markedly increased in sputum and exhaled breath of patients with COPD [181, 184] and are further increased during exacerbations [185-188]. In patients with $\alpha_{1}$ antitrypsin $\left(\alpha_{1}-\mathrm{AT}\right)$ deficiency, $\mathrm{LTB}_{4}$ is the major neutrophil chemoattractant in the airways [189]. Use of selective $\mathrm{BLT}_{1^{-}}$ receptor antagonists has demonstrated that $\mathrm{LTB}_{4}$ contributes towards the neutrophil chemotactic activity in COPD secretions [190]. Recent studies indicate that in addition to neutrophil chemotactic activities, $\mathrm{LTB}_{4}$ also has potent immunomodulatory effects [191] and is a potent attractant of $\mathrm{CD}^{+}$ T-cells via $\mathrm{BLT}_{1}$-receptors [192].

BLT $_{1}$-receptor antagonists, such as LY29311, have now been developed for the treatment of neutrophilic inflammation [193]. LY293111 and another antagonist SB225002 inhibit the neutrophil chemotactic activity of sputum from COPD patients, indicating the potential clinical value of such drugs $[185,190]$ and several selective $\mathrm{BLT}_{1}$ antagonists are now in development. $\mathrm{LTB}_{4}$ is synthesised by $5^{\prime}$-lipoxygenase, although there have been problems in clinical development of $5^{\prime}$ lipoxygenase inhibitors because of side-effects (particularly hepatic toxicity). A recent pilot study in COPD patients with a 5'-lipoxygenase inhibitor BAYx1005 showed only a modest reduction in sputum $\mathrm{LTB}_{4}$ concentrations but no effect on neutrophil activation markers [194]. More appropriately, powered studies in COPD are required with more potent $5^{\prime}$ lipoxygenase inhibitors or $\mathrm{BLT}_{1}$-receptor antagonists.

\section{Tumour necrosis factor-a inhibitors}

TNF- $\alpha$ and soluble TNF receptor concentrations are raised in the sputum of COPD patients [195, 196]. TNF- $\alpha$ augments inflammation and induces IL- 8 and other chemokines in airway cells via activation of NF- $\kappa \mathrm{B}$. The severe wasting in some patients with advanced COPD might be due to skeletal muscle apoptosis, resulting from increased circulating TNF- $\alpha$ [197], which may be released from circulating leukocytes [198]. Humanised monoclonal TNF antibody (infliximab) and soluble TNF receptors (etanercept) that are effective in other chronic inflammatory diseases, such as rheumatoid arthritis and inflammatory bowel disease, may, therefore, be effective in COPD, particularly in patients who have systemic symptoms [199]. Trials of anti-TNF therapies in patients with systemic features of COPD are currently underway. TNF- $\alpha$-converting enzyme (TACE), which is required for the release of soluble TNF- $\alpha$, may be a more attractive target as it is possible to discover small molecule TACE inhibitors, some of which are also matrix metalloproteinase (MMP) inhibitors [200]. General anti-inflammatory drugs, such as PDE4 inhibitors and p38 mitogen-activated protein kinase (MAPK) inhibitors, are also potent inhibitors of TNF- $\alpha$ synthesis.

\section{Other cytokine targets}

There are other potential cytokine targets in COPD [201], including IL- $1 \beta$ which has similar amplifying effects to TNF- $\alpha$ and the endogenous inhibitor IL-1 receptor antagonist (anakinra) which is already in a clinical trial for inflammatory diseases [202]. IL-6 concentrations are increased in sputum and exhaled breath of COPD patients $[203,204]$ and in plasma of patients during exacerbations [205]. The functional consequences of IL- 6 are uncertain but may relate to some of the systemic features of the disease. Blocking antibodies to IL-6 are now in clinical development for the treatment of a variety of inflammatory diseases [206] and should be explored in COPD. Other potential cytokine targets include IL-11 and IL-17 [180].

\section{Transforming growth factor- $\beta$ inhibitors}

Transforming growth factor (TGF)- $\beta 1$ is highly expressed in airway epithelium and macrophages of small airways in patients with COPD [207, 208]. It is a potent inducer of fibrosis, partly via the release of the potent fibrogenic mediator, connective tissue growth factor. It may also be important in inducing the fibrosis and narrowing of peripheral airways (obstructive bronchiolitis) in COPD [6]. TGF- $\beta 1$ also activates MMP-9, which then further activates TGF- $\beta 1$, thus providing a link between small airway fibrosis and emphysema in COPD. MMP-9 can also inactivate TGF- $\beta$-binding protein 1 , and this may be a mechanism for the physiological release of TGF- $\beta 1$ [209]. TGF- $\beta 1$ also down-regulates $\beta_{2}$-adrenoceptors [210] and impairs bronchodilator responses to $\beta_{2}$-agonists [211]. Inhibition of TGF- $\beta 1$ signalling may, therefore, be a useful therapeutic strategy in COPD. Small molecule antagonists that inhibit TGF- $\beta 1$ receptor kinase are now in development [212], although the long-term safety of such drugs might be a 
problem, particularly as TGF- $\beta 1$ affects tissue repair and is a potent anti-inflammatory mediator.

\section{Chemokine inhibitors}

Several chemokines are involved in the chemotaxis and recruitment of neutrophils, monocytes and T-cells into the lungs of COPD patients [180]. These act on chemokine receptors, which are G-protein coupled receptors that are, thus, targets for small molecule inhibitors (fig. 4) [213, 214].

\section{IL-8}

IL-8 is a CXC chemokine which is markedly elevated in the sputum of patients with COPD. It is present early in the development of emphysema [215] and is correlated with disease severity $[195,216]$. Blocking antibodies to IL-8 and related chemokines inhibit neutrophilic inflammation in experimental animals [217], and reduce the chemotactic response of neutrophils to sputum from COPD patients [184, 190]. A human monoclonal neutralising antibody to IL-8 has been tested in COPD, and while it had a small effect in reducing dyspnoea scores, there was no other clinical improvement [218].

\section{Other CXC chemokines}

Other CXC chemokines are also involved in COPD. IL-8 activates neutrophils via a specific low-affinity G-protein coupled receptor (CXCR1) linked to activation and degranulation and via a high-affinity receptor (CXCR2), shared with other members of the CXC family and is important in the chemotactic response. Other CXC chemokines that activate CXCR2 receptors, such as growth related oncoprotein- $\alpha$ (GRO$\alpha)$, are also elevated in COPD [219] and, therefore, a CXCR2 antagonist is likely to be more useful than a CXCR1 antagonist. CXCR2 receptors are also expressed on monocytes and inhibition of monocyte chemotaxis may prevent the marked increase in macrophages found in the lungs of patients with COPD [220]. As this cell has been implicated in orchestrating the inflammatory events central to the pathogenesis of COPD [221], small molecule inhibitors of CXCR2, such as SB225002, may prove to be particularly beneficial and are now entering clinical trials [214, 222]. These drugs may also be useful in exacerbations of COPD when CXCR2 are upregulated in the airways [223] and in mucus hypersecretion which may be mediated via CXCR2 in experimental virus-induced exacerbations [224].

\section{CC chemokines}

There is increased expression of the CC chemokine monocyte chemotactic protein (MCP)-1 and its receptor, CCR2, on macrophages and epithelial cells from COPD patients and this may also play a role in the recruitment of blood monocytes to the lungs of COPD patients [225]. MCP-1 is markedly elevated in COPD patients [219] so that CCR2 antagonists may be of use and several small molecule CCR2 antagonists are now in clinical development.

Chemokine receptors are also important for the recruitment of CD8+ T-cells which predominate in COPD airways and lungs, and might contribute to the development of emphysema [226, 227]. CD8+ cells show increased expression of CXCR3 and there is upregulation of CXCR3 ligands, such as CXCL10 (IP10), in peripheral airways of COPD patients [228], which suggests that CXCR3 antagonists might also be useful.

\section{ANTIOXIDANTS}

Oxidative stress is increased in patients with COPD [229-231], particularly during exacerbations, and reactive oxygen species contribute to its pathophysiology $[232,233]$. This suggests that antioxidants may be of use in the therapy of COPD.

\section{Antioxidants}

$\mathrm{N}$-acetyl cysteine (NAC) provides cysteine for enhanced production of the antioxidant glutathione and has antioxidant effects in vitro and in vivo. A systematic review of studies with oral NAC in COPD suggested a small reduction in exacerbations [234] and a larger more prolonged trial is now underway [235]. Nacystelyn is a related thiol antioxidant that is effective in vitro and in vivo animal models [236] and may be suitable for nebulised delivery. More effective antioxidants, including
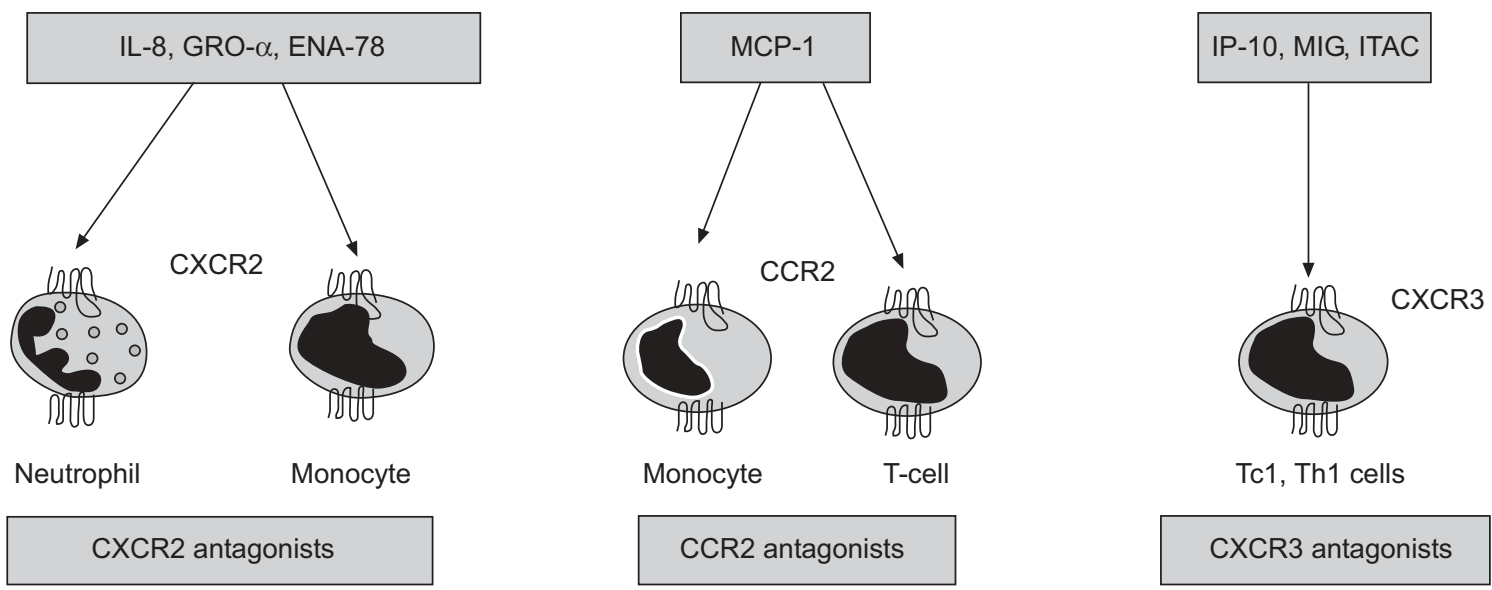

CXCR3 antagonists

FIGURE 4. Antagonism of chemokine receptors in chronic obstructive pulmonary disease (COPD). Chemokine receptors involved in cell recruitment in COPD include CXCR2, CCR2 and CXCR3. Small molecule inhibitors have now been developed for all of these receptors. IL: interleukin; GRO: growth-related oncoprotein; ENA: epithelial neutrophil-activating protein; MCP: monocyte chemotactic protein; IP: interferon-inducible protein; MIG: monokine induced by interferon- $\gamma$; ITAC: interferon-inducible T-cell alpha chemoattractant; CXCR/CCR: chemokine receptors; Tc: cytotoxic T-cell; Th: helper T-cell. 
stable glutathione compounds, analogues of superoxide dismutase and selenium-based drugs, are now in development for clinical use [232, 233, 237].

\section{Resveratrol}

Resveratrol is a phenolic component of red wine that has antiinflammatory and antioxidant properties. It has a marked inhibitory effect on cytokine release from alveolar macrophages obtained from COPD patients that show little or no response to corticosteroids [238]. The molecular mechanism of this action is currently unknown [239], but identification of the cellular target for resveratrol may lead to the development of a novel class of anti-inflammatory compounds. Resveratrol itself has a very low oral bioavailability so related drugs or a suitable inhaled formulation will need to be developed if such agents are to be effective.

\section{Nitric oxide synthase inhibitors}

Oxidative stress and increased NO release (by increased activity of inducible NO synthase (iNOS)) may result in the formation of peroxynitrite; this is a potent radical that nitrates proteins and alters their function. Peroxynitrite may also lead to steroid resistance in COPD through nitration and inactivation if histone deacetylase-2 [90, 91]. 3-Nitrotyrosine may indicate peroxynitrite formation and is markedly increased in sputum macrophages of patients with COPD [240]. Selective inhibitors of iNOS are now in development and one of these, a

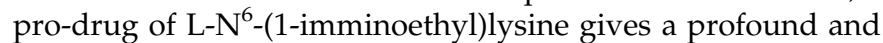
long-lasting reduction in the concentrations of $\mathrm{NO}$ in exhaled breath [241]. Inhibition of peroxynitrite generation by antioxidants or iNOS inhibitors seems a logical approach in COPD and may restore steroid responsiveness, as discussed previously [242].

\section{SIGNAL TRANSDUCTION PATHWAY INHIBITORS}

Structural and inflammatory cells are activated in COPD lungs via multiple signal transduction pathways that are potential targets for inhibition. Several inhibitors of enzymes, such as kinases, involved in these pathways have now been developed and are in clinical development [243], but issues about specificity and safety of this approach still remain.

\section{NF-кB inhibitors}

$\mathrm{NF}-\kappa \mathrm{B}$ regulates the expression of IL- 8 and other chemokines, TNF- $\alpha$ and other inflammatory cytokines, and some MMPs (fig. 5). NF- $\kappa \mathrm{B}$ is activated in macrophages and epithelial cells of COPD patients, particularly during exacerbations [244, 245]. There are several possible approaches to inhibition of NF- $\kappa \mathrm{B}$, including gene transfer of the inhibitor of NF- $\kappa B(\mathrm{I} \kappa \mathrm{B})$,

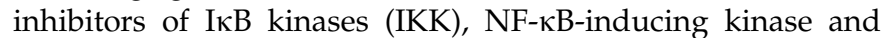
I $\kappa$ B ubiquitin ligase, which regulate the activity of NF- $\kappa B$, and inhibit the degradation of IкB [246]. The most promising approach may be the inhibition of IKK-2 by small molecule inhibitors [247], which suppress the release of inflammatory cytokines and chemokines from alveolar macrophages [248] and might, therefore, be effective in COPD, particularly as alveolar macrophages are resistant to the anti-inflammatory actions of corticosteroids [88]. One concern about long-term inhibition of NF- $\kappa B$, however, is that effective inhibitors may result in immune suppression and impair host defences, since mice which lack NF- $\kappa$ B genes succumb to septicaemia.

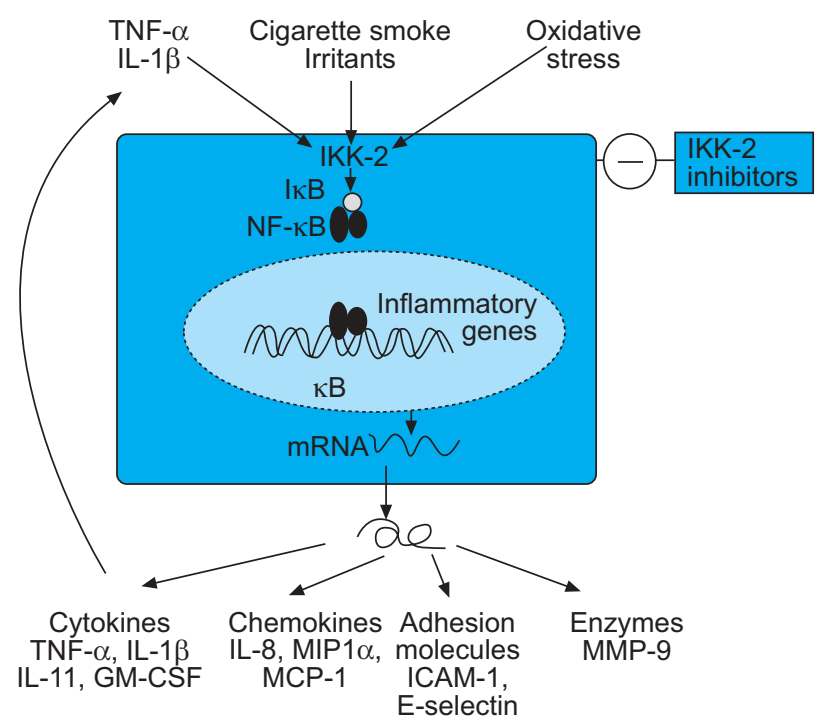

FIGURE 5. Inhibition of nuclear factor- $\mathrm{B}$ (NF- $\mathrm{kB})$ by blockade of inhibitor of NF-кB kinase-2 (IKK-2), the key activating enzyme, should inhibit the expression of multiple inflammatory genes that are expressed in chronic obstructive pulmonary

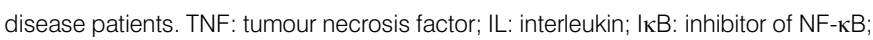
GM-CSF: granulocyte macrophage-colony stimulating factor; MIP: macrophage inflammatory protein; MCP: monocyte chemotactic protein; ICAM: intracellular adhesion molecule; MMP: matrix metalloproteinase.

However, there are alternative pathways of NF- $\kappa \mathrm{B}$ activation via kinases other than IKK that might be more important in inflammatory disease and have less potential effect on innate and adaptive immune responses [249].

\section{p38 MAPK inhibitors}

MAPKs play a key role in chronic inflammation and several complex enzyme cascades have now been defined [250]. One of these, the p38 MAPK pathway, is activated by cellular stress and regulates the expression of inflammatory cytokines, including IL-8, TNF- $\alpha$ and MMPs (fig. 6) [251]. Small molecule inhibitors of p38 MAP kinase, such as SB 203580, SB 239063 and RWJ 67657, have been developed and these drugs have a broad range of anti-inflammatory effects [252]. SB 239063 reduces neutrophil infiltration and the concentrations of IL-6 and MMP-9 in BALF of rats after inhaled endotoxin, indicating its potential as an anti-inflammatory agent in COPD [253]. It is likely that such a broad spectrum anti-inflammatory drug will have some toxicity or impair natural immune responses, but inhalation may be a feasible therapeutic approach.

\section{Phosphoinositide 3-kinase inhibitors}

Phosphoinositide 3-kinase inhibitors (PI-3K) are a family of enzymes that lead to the generation of lipid second messengers that regulate a number of cellular events. A particular isoform, $\mathrm{PI}-3 \mathrm{~K} \gamma$, is involved in neutrophil and monocyte recruitment and activation. Knockout of the PI-3K $\gamma$ gene results in inhibition of neutrophil migration and activation, as well as impaired T-lymphocyte and macrophage function [254]. This suggests that selective PI-3K $\gamma$ inhibitors may have relevant anti-inflammatory activity in COPD and small molecule inhibitors of PI-3K $\gamma$ are in development [255]. 


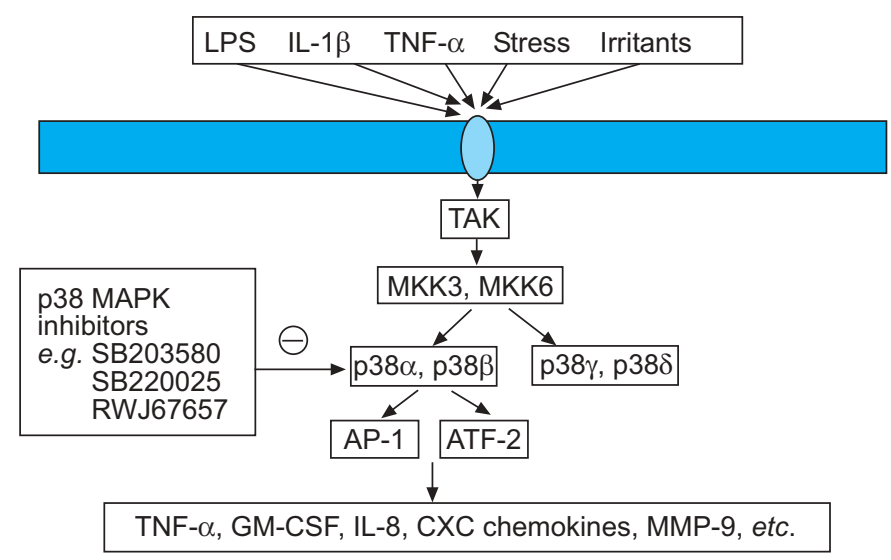

FIGURE 6. Inhibition of p38 mitogen-activated protein kinase (MAPK) by selective inhibitors should inhibit the expression of several activated inflammatory genes in chronic obstructive pulmonary disease patients. LPS: lipopolysaccharide IL: interleukin; TNF: tumour necrosis factor; TAK: transforming growth factor- $\beta$ activated kinase; MKK: mitogen-activated protein kinase kinase; AP: activator protein; GM-CSF: granulocyte macrophage-colony stimulating factor; MMP: matrix metalloproteinases.

\section{PPAR activators}

Peroxisome proliferator-activated receptors (PPARs) are a family of ligand-activated nuclear hormone receptors belonging to the steroid receptor superfamily, and the three recognised subtypes PPAR $-\alpha,-\gamma$ and $-\delta$ are widely expressed. There is evidence that activation of PPAR- $\alpha$ and PPAR- $\delta$ may have anti-inflammatory and immunomodulatory effects. For example, PPAR- $\gamma$ agonists, such as troglitazone, inhibit the release of inflammatory cytokines from monocytes and induce apoptosis of T-lymphocytes [256-258], suggesting that they may have anti-inflammatory potential in COPD, where these cells are thought to play central pathogenic roles.

\section{PROTEINASE INHIBITORS}

There is an imbalance between proteinases that digest elastin (and other structural proteins) and antiproteinases that protect against this $[259,260]$. This suggests that either inhibiting these proteolytic enzymes or increasing endogenous antiproteinases $\left(\alpha_{1}-\mathrm{AT}\right.$, elafin, secretory leukoprotease inhibitor, tissue inhibitor of MMP) may be beneficial and theoretically should prevent the progression of airflow obstruction in COPD. Considerable progress has been made in identifying the enzymes involved in elastolytic activity in emphysema and in characterising the endogenous antiproteinases that counteract this activity [260]. The fact that there are so many proteinases implicated in COPD might mean that blocking a single enzyme may not have a complete effect.

\section{Neutrophil elastase inhibitors}

Neutrophil elastase is a serine protease mainly derived from neutrophils that has potent elastolytic effects and may also active other proteinases. Neutrophil elastase is inhibited predominantly by $\alpha_{1}$-AT, which is currently given as an extracted protein to patients with serum deficiency and lung disease [261]. $\alpha_{1}$-AT could be delivered either in recombinant form or by viral vector gene delivery in the future [262, 263], but these approaches are problematic as large amounts of protein are required and gene therapy is unlikely to provide sufficient protein. Furthermore, delivery to the periphery of the lung, where the proteolytic damage causing emphysema occurs, presents considerable technical problems. Although $\alpha_{1^{-}}$ AT augmentation is the logical treatment of choice for patients with severe $\alpha_{1}$-AT deficiency, its efficacy has yet to be clearly shown. A limited controlled trial of intravenous purified $\alpha_{1}$-AT had disappointingly few beneficial effects [264]. There is less reason to suppose it would be effective in COPD patients where there is no $\alpha_{1}$-AT deficiency, although free neutrophil elastase activity is often detected especially during exacerbations $[104,186]$. Since this enzyme can cause many of the features of COPD (mucous gland hyperplasia, mucus secretion, impaired ciliary function) and impaired lung immunity, its inhibition remains a potential therapy in such patients [265] However, additional proteinases are likely to be involved in many aspects of COPD and may also need appropriate control.

An alternative approach is to develop small molecule inhibitors of neutrophil elastase [266] and ONO-5046 and FR901277 have high potency [267]. These drugs inhibit neutrophil elastase-induced lung injury in experimental animals, whether given by inhalation or systemically and also inhibit the other serine proteinases released from neutrophils, namely cathepsin G and proteinase-3, that may mediate features of COPD. Small molecule inhibitors of neutrophil elastase are in clinical development, but there is concern that neutrophil elastase is critical for normal physiological function and may not play a critical role even in emphysema.

Despite all of the data implicating proteinases in the pathogenesis of COPD, the potential complexities involved have delayed drug development. However, interventional studies are urgently required to make progress. Since neutrophil elastase, proteinase-3, cathepsin $G$ and cathepsin B are the only enzymes shown directly to produce the pathological features of COPD this seems an appropriate starting point. Indeed, neutrophil elastase is required to activate cathepsin B [268] and may do the same for MMPs [269], whilst inactivating their inhibitors [270]. It is, therefore, possible that neutrophil elastase is central to a proteinase cascade and, hence, remains a key target to prevent proteolytic lung damage in COPD.

\section{Cysteine protease inhibitors}

The role of cysteine proteinases in COPD has not been defined, although they do contribute to the elastolytic activity of alveolar macrophages in COPD patients [271]. Inhibitors of elastolytic cysteine proteinases, such as cathepsins B, K, S and $\mathrm{L}$, that are released from macrophages, are also in development [272].

\section{MMP inhibitors}

MMPs with elastolytic activity (such as MMP-9 and MMP-12) are also a target for drug development, although nonselective MMP inhibitors, such as marimastat, appear to have considerable musculoskeletal side-effects [273]. There is now a search for more selective inhibitors [274] and side-effects could be reduced by increasing selectivity for specific MMPs or by targeting delivery to the lung parenchyma. MMP-9 is markedly overexpressed by alveolar macrophages from patients with COPD and is the major elastolytic enzyme released by these cells [275], so a selective MMP-9 inhibitor might prove to be useful in the treatment of emphysema. Such inhibitors may be of particular 
value as MMP also activates TGF- $\beta$, inactivates $\alpha 1-\mathrm{AT}$ and generates neutrophil chemotactic peptides (fig. 7).

\section{MUCOREGULATORS}

Mucus hypersecretion is commonly seen in cigarette smokers, but is not necessarily associated with airflow limitation. In individuals with COPD, mucus hypersecretion is associated with a more rapid decline in FEV1 and may increase the frequency of exacerbations [276], which in themselves may affect the decline in FEV1 $[106,116]$. Reducing mucus hypersecretion may, therefore, have therapeutic benefit, although suppression of the normal airway mucus secretion may be detrimental. Mucolytic drugs have been used for many years to reduce mucus viscosity but these drugs do not appear to have any clinical value. Several novel approaches to inhibiting mucus hypersecretion are currently being explored [277]. Mucus hypersecretion appears to be largely driven in COPD by the neutrophil inflammatory response, so that effective antiinflammatory treatments directed at this cell or its products would be expected to reduce mucus hypersecretion [277].

\section{EGFR inhibitors}

Epidermal growth factor receptors (EGFRs) play a critical role in airway mucus secretion from goblet cells and submucosal glands and appears to mediate the mucus secretory response to several secretagogues, including oxidative stress, cigarette smoke and inflammatory cytokines [278]. EGFRs may also be responsible for the mucous cell hyperplasia seen in chronic bronchitis. Small molecule inhibitors of EGFR kinase, such as gefitinib and erlotinib, have now been developed for the treatment of nonsmall cell lung cancer and are worth exploring in COPD patients.

\section{Chloride channel inhibitors}

Another novel approach involves inhibition of calciumactivated chloride channels (CACC), which are important in

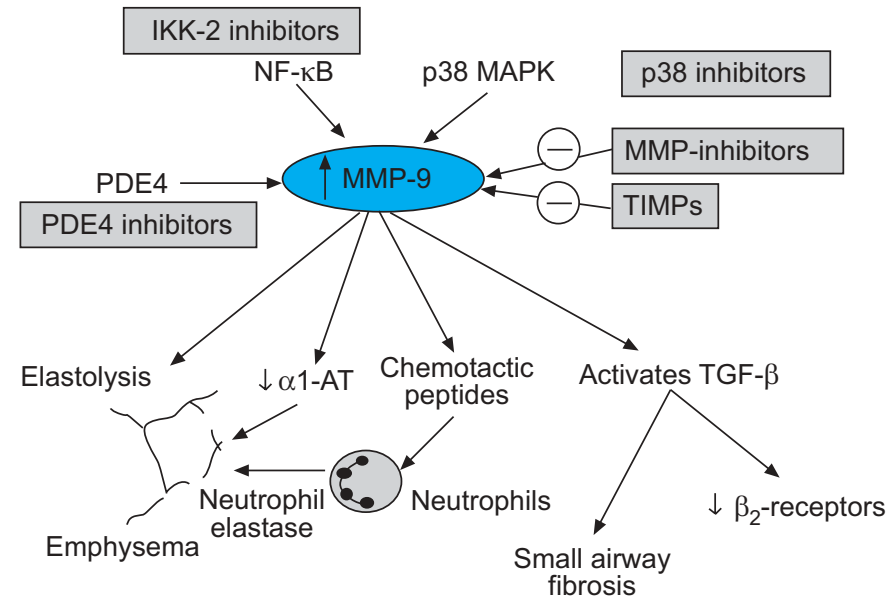

FIGURE 7. Inhibition of matrix metalloprotease (MMP)-9 should inhibit the multiple effects of this protease that are relevant in chronic obstructive pulmonary disease patients, including elastolysis, inactivation of $\alpha_{1}$-antitrypsin $\left(\alpha_{1}\right.$-AT), neutrophil chemotaxis, activation of transforming growth factor (TGF)- $\beta$. There are several approaches, including small molecule inhibitors, tissue inhibitors of MMPs (TIMPs), and inhibition of nuclear factor- $\mathrm{KB}(\mathrm{NF}-\kappa \mathrm{B})$, phosphodiesterase-4 (PDE4) and p38 mitogen-activated protein kinase (MAPK). IKK-2: inhibitor of IKB kinase-2. mucus secretion from goblet cells. Activation of the human calcium-activated chloride channel (hCLCA1) induces mucus secretion and mucus gene expression and may, therefore, be a target for inhibition. Small molecule inhibitors of CACC, such as niflumic acid and talniflumate, have been developed but have yet to be tested in COPD $[279,280]$.

\section{Other approaches}

Other approaches include inhibition of the neural mechanisms driving mucus secretion, including tachykinin receptor antagonists, $\mathrm{P} 2 \mathrm{Y}_{2}$ purinergic receptor antagonists and potassium-channel openers [281]. Proteinase inhibitors and PDE4 inhibitors (see earlier) should also be effective in inhibiting mucus hypersecretion.

\section{PULMONARY VASODILATORS}

Pulmonary hypertension may occur in $20-40 \%$ of patients with severe COPD and the elevation of pulmonary arterial pressure correlates inversely with $\mathrm{Pa}_{1} \mathrm{O}_{2}$ and FEV1. The degree of pulmonary hypertension in COPD patients is relatively mild at rest, but increases during exercise, during nocturnal desaturation and with exacerbations. The cause of pulmonary hypertension in COPD is likely to be a combination of hypoxic vasoconstriction, structural remodelling of small pulmonary arteries and destruction of the pulmonary vascular bed as a result of emphysema [282]. In addition, there is a chronic inflammatory process (as in small airways) affecting pulmonary vessels, raising the possibility that anti-inflammatory treatments may also affect pulmonary vascular tone [283]. As discussed previously, LTOT is recommended for the treatment of pulmonary hypertension, but there is no evidence that it reverses pulmonary hypertension and it remains very expensive. This has prompted a search for pharmacological pulmonary vasodilators.

Several vasodilators such as calcium channel blockers, hydralazine, ACE inhibitors or angiotensin antagonists reduce pulmonary arterial pressure acutely, although the results have been disappointing and there is also a concomitant reduction in systemic blood pressure, which may be detrimental [284].

\section{Endothelin antagonists}

Endothelin (ET)-1 is a potent pulmonary vasoconstrictor and also induces fibrosis. There is increased expression of ET-1 around pulmonary vessels in patients with COPD who have hypertension [285]. The oral ET receptor antagonist bosentan has been shown to have benefit in primary pulmonary hypertension, but its effect in COPD pulmonary hypertension is unknown [286]. ET antagonists, however, have the potential to also reduce the pulmonary remodelling process, which may prove detrimental in subjects with ongoing inflammation [287].

\section{Prostacyclin derivatives}

Prostacyclin is a potent pulmonary vasodilator but needs to be given by intravenous infusion and has a short half-life. Stable prostacyclin analogues, including treprostinil, may be given by subcutaneous injection, beraprost orally and ileoprost by inhalation [288]. Their benefit in COPD is not yet known.

\section{PDE5 inhibitors}

PDE5 predominates in vascular smooth muscle and PDE4 inhibitors, such as sildenafil and tadalafil, reduce hypoxic pulmonary vasoconstriction and arterial remodelling in 
animals and so have potential in COPD patients with pulmonary hypertension [289].

\section{FUTURE DIRECTIONS}

It is clear that the current therapy of COPD is far from ideal and that improved therapies are needed [5]. There are several approaches to discovering new therapies, but more research into the basic cellular, molecular and genetic abnormalities of COPD are needed, as well as better ways to phenotype patients and identify useful biomarkers of disease.

\section{Gene microarray}

It is important to identify the genetic factors that determine why only a minority of heavy smokers develop significant COPD [290]. Identification of genes that predispose to the development of COPD may provide novel therapeutic targets. Use of gene microarrays may help to identify known and unknown genetic targets and to differentiate different forms of the disease that may respond differently to therapy. For example, distinct patterns of antioxidant gene expression have been identified in airway epithelial cells of smokers [291] and in neutrophils after endotoxin exposure [292]. This approach may lead to the identification of genes involved in amplification of the inflammatory process in COPD that may facilitate the discovery of novel drug targets.

\section{Proteomics}

Proteomics is complementary to gene microarray and by use of high-resolution 2-dimentional electrophoresis allows the detection of multiple proteins in fluids, cells and tissues [293]. This could show patterns of protein expression that relate to specific phenotypes of COPD and may identify new or more appropriate targets, particularly in subsets of patients.

\section{Clinical trials in COPD}

Clinical trials in COPD are a challenge and there is a need in future to define phenotypes of the disease more clearly. For example, it may be important to differentiate patients who are mucus hypersecretors, who have predominant small airway disease or emphysema, systemic effects or pulmonary hypertension and also to study patients of differing severity. As the progression of COPD is very slow and variable between patients it is necessary to include large numbers of patients in clinical trials and to study them over 3 yrs or more to obtain clearly identified outcomes. This presents a major problem in the development of new drugs and indicates the urgent need to identify surrogate markers and biomarkers that may predict disease progression or response to treatment in order to provide confidence in the progression to expensive long-term studies of clinical outcome.

\section{Surrogate markers}

For novel anti-inflammatory therapies it is important to demonstrate anti-inflammatory effects in COPD patients by measurement of selected inflammatory markers in sputum, bronchial biopsies or bronchoalveolar lavage. The specific biomarkers selected will depend on the mechanism of action of the drug. There are no validated challenges in COPD, such as have been developed in asthma, so changes in baseline measurements or during naturally occurring exacerbations are used.
Exhaled breath analysis of volatile compounds or breath condensate provides a noninvasive means of measuring inflammatory markers (lipid mediators, reactive oxygen/ nitrogen species, some cytokines) [294]. The use of imaging techniques, such as high-resolution computerised tomography, to measure disease progression is another promising approach as scanning resolution increases [295].

It may also be important to define the presence of emphysema versus small airway obstruction more accurately using highresolution computed tomography scans, as some drugs may be more useful for preventing emphysema, whereas others may be more effective against the small airway inflammatoryfibrotic process. More research on the basic cellular and molecular mechanisms of chronic obstructive pulmonary disease is urgently needed to aid the logical development of new therapies for this common and important disease, and for which no effective preventative treatments currently exist.

\section{ACKNOWLEDGEMENTS}

We dedicate this review to Romain Pauwels who died this year. Romain was involved in setting up the workshops on "COPD: the important questions" and was part of the early discussions on the workshop from which this review is derived. He made enormous contributions to research in COPD and, through his leadership of the GOLD Initiative, to its greater recognition and improved management throughout the world.

The current review is a summary of a meeting on "COPD: the important questions" held in Marbella, Spain, in April 2004. The meeting was sponsored by AstraZeneca and chaired by P.J. Barnes (UK) and R.A. Stockley (UK). The following also participated in the meeting: N. Anthonisen (Canada), J. Book (Sweden), P. Calverley (UK), R. Casaburi (USA), M. Decramer (Belgium), M. Elliott (UK), D. Geddes (UK), M. Giembycz (Canada), T. Hansel (UK), T. Higenbottam (UK), S. Kunkel (USA), M. Luisetti (Italy), J. Lund (Sweden), W. MacNee (UK), N. Morrell (UK), R. Newton (UK), U. Nihlen (Sweden), S. Rennard (USA), D. Rogers (UK), A. Schols (The Netherlands), D. Silberstein (Sweden), S. Simonson (Sweden), I. Stolerman (UK) and A. Young (UK). The aim of the meeting was to identify important questions related to the current and future therapy of chronic obstructive pulmonary disease and to discuss new therapeutic approaches based on recent and evolving research.

\section{REFERENCES}

1 Rennard SI. Treatment of stable chronic obstructive pulmonary disease. Lancet 2004; 364: 791-802.

2 Sutherland ER, Cherniack RM. Management of chronic obstructive pulmonary disease. N Engl J Med 2004; 350: 2689-2697.

3 Barnes PJ, Shapiro SD, Pauwels RA. Chronic obstructive pulmonary disease: molecular and cellular mechanisms. Eur Respir J 2003; 22: 672-688.

4 Barnes PJ. New treatments for COPD. Nat Rev Drug Disc 2002; 1: 437-445.

5 Barnes PJ, Hansel TT. Prospects for new drugs for chronic obstructive pulmonary disease. Lancet 2004; 364: 985-996. 
6 Hogg JC, Chu F, Utokaparch S, et al. The nature of smallairway obstruction in chronic obstructive pulmonary disease. N Engl J Med 2004; 350: 2645-2653.

7 Barnes PJ. Small airways in COPD. N Engl J Med 2004; 350: 2635-2637.

8 Thannickal VJ, Toews GB, White ES, Lynch JP III, Martinez FJ. Mechanisms of pulmonary fibrosis. Annu Rev Med 2004; 55: 395-417.

9 Shapiro SD. Animal models for COPD. Chest 2000; 117: Suppl. 1, 223S-227S.

10 Dawkins PA, Stockley RA. Animal models of chronic obstructive pulmonary disease. Thorax 2001; 56: 972-977.

11 Anthonisen NR, Connett JE, Kiley JP, et al. Effects of smoking intervention and the use of an inhaled anticholinergic bronchodilator on the rate of decline of $\mathrm{FEV}_{1}$. JAMA 1994; 272: 1497-1505.

12 Scanlon PD, Connett JE, Waller LA, Altose MD, Bailey WC, Buist AS. Smoking cessation and lung function in mild-to-moderate chronic obstructive pulmonary disease. The Lung Health Study. Am J Respir Crit Care Med 2000; 161: 381-390.

13 Wagena EJ, van der Meer RM, Ostelo RJ, Jacobs JE, Van Schayck CP. The efficacy of smoking cessation strategies in people with chronic obstructive pulmonary disease: results from a systematic review. Respir Med 2004; 98: 805-815.

14 Tashkin DP, Kanner R, Bailey W, et al. Smoking cessation in patients with chronic obstructive pulmonary disease: a double-blind, placebo controlled, randomised trial. Lancet 2001; 357: 1571-1575.

15 Roddy E. Bupropion and other non-nicotine pharmacotherapies. BMJ 2004; 328: 509-511.

16 George TP, O’Malley SS. Current pharmacological treatments for nicotine dependence. Trends Pharmacol Sci 2004; 25: 42-48.

17 Cryan JF, Gasparini F, van Heeke G, Markou A. Nonnicotinic neuropharmacological strategies for nicotine dependence: beyond bupropion. Drug Discov Today 2003; 8: 1025-1034.

18 Dani JA. Roles of dopamine signaling in nicotine addiction. Mol Psychiatry 2003; 8: 255-256.

19 Foulds J, Burke M, Steinberg M, Williams JM, Ziedonis DM. Advances in pharmacotherapy for tobacco dependence. Expert Opin Emerg Drugs 2004; 9: 39-53.

20 Cohen C, Bergis OE, Galli F, et al. SSR591813, a novel selective and partial $\alpha 4 \beta 2$ nicotinic receptor agonist with potential as an aid to smoking cessation.J Pharmacol Exp Ther 2003; 306: 407-420.

21 Kantak KM. Vaccines against drugs of abuse: a viable treatment option? Drugs 2003; 63: 341-352.

22 Sin DD, McAlister FA, Man SF, Anthonisen NR. Contemporary management of chronic obstructive pulmonary disease: scientific review. JAMA 2003; 290: 2301-2312.

23 Tashkin DP, Cooper CB. The role of long-acting bronchodilators in the management of stable COPD. Chest 2004; 125: 249-259.

24 Appleton S, Poole P, Smith B, Veale A, Bara A. Longacting $\beta_{2}$-agonists for chronic obstructive pulmonary disease patients with poorly reversible airflow limitation. Cochrane Database Syst Rev 2002; 3: CD001104.
25 Cazzola $M$, Donner CF. Long-acting $\beta_{2}$ agonists in the management of stable chronic obstructive pulmonary disease. Drugs 2000; 60: 307-320.

26 D'Urzo AD, De Salvo MC, Ramirez-Rivera A, et al. In patients with COPD, treatment with a combination of formoterol and ipratropium is more effective than a combination of salbutamol and ipratropium: a 3-week, randomized, double-blind, within-patient, multicenter study. Chest 2001; 119: 1347-1356.

27 Sovani MP, Whale CI, Tattersfield AE. A benefit-risk assessment of inhaled long-acting $\beta_{2}$-agonists in the management of obstructive pulmonary disease. Drug Safety 2004; 27: 689-715.

28 Tattersfield AE, Lofdahl CG, Postma DS, et al. Comparison of formoterol and terbutaline for as-needed treatment of asthma: a randomised trial. Lancet 2001; 357: 257-261.

29 Goldkorn A, Diotto P, Burgess C, et al. The pulmonary and extra-pulmonary effects of high-dose formoterol in COPD: a comparison with salbutamol. Respirology 2004; 9: 102-108.

30 Cazzola M, Santus P, Matera MG, et al. A single high dose of formoterol is as effective as the same dose administered in a cumulative manner in patients with acute exacerbation of COPD. Respir Med 2003; 97: 458-462.

31 Johnson $M$, Rennard S. Alternative mechanisms for longacting $\beta_{2}$-adrenergic agonists in COPD. Chest 2001; 120 : 258-270.

32 Jeffery PK, Venge P, Gizycki MJ, Egerod I, Dahl R, Faurschou P. Effects of salmeterol on mucosal inflammation in asthma: a placebo-controlled study. Eur Respir J 2002; 20: 1378-1385.

33 Reid DW, Ward C, Wang N, et al. Possible antiinflammatory effect of salmeterol against interleukin-8 and neutrophil activation in asthma in vivo. Eur Respir J 2003; 21: 994-999.

34 Maris NA, van der Sluijs KF, Florquin S, et al. Salmeterol, a $\beta_{2}$-receptor agonist, attenuates lipopolysaccharideinduced lung inflammation in mice. Am J Physiol Lung Cell Mol Physiol 2004; 286: L1122-L1128.

35 Ottonello L, Morone P, Dapino P, Dallegri F. Inhibitory effect of salmeterol on the respiratory burst of adherent human neutrophils. Clin Exp Immunol 1996; 106: 97-102.

36 Bloemen PG, van den Tweel MC, Henricks PA, et al. Increased cAMP levels in stimulated neutrophils inhibit their adhesion to human bronchial epithelial cells. Am J Physiol 1997; 272: L580-L587.

37 Tokoyama K, Lotvall JO, Lofdahl C-G, Barnes PJ, Chung KF. Inhaled formoterol inhibits histamine induced airflow obstruction and airway microvascular leakage. Eur J Pharmacol 1991; 193: 35-40.

38 Bolton PB, Lefevre P, McDonald DM. Salmeterol reduces early- and late-phase plasma leakage and leukocyte adhesion in rat airways. Am J Respir Crit Care Med 1997; 155: 1428-1435.

39 Bowden JJ, Anderson GP, Lefevre PM, Sulakvelidze I, McDonald DM. Characterization of tolerance to the antileakage effect of formoterol in rat airways. Eur J Pharmacol 1997; 338: 83-87.

40 Devalia JL, Sapsford RJ, Rusznak C, Toumbis MJ, Davies RJ. The effects of salmeterol and salbutamol on 
ciliary beat frequency of cultured human bronchialepithelial cells in vitro. Pulm Pharmacol 1992; 5: 257-263.

41 Lindberg S, Khan R, Runer T. The effects of formoterol, a long-acting $\beta_{2}$-adrenoceptor agonist, on mucociliary activity. Eur J Pharmacol 1995; 285: 275-280.

42 Dowling RB, Rayner CF, Rutman A, et al. Effect of salmeterol on Pseudomonas aeruginosa infection of respiratory mucosa. Am J Respir Crit Care Med 1997; 155: 327-336.

43 Dowling RB, Johnson M, Cole PJ, Wilson R. Effect of salmeterol on Haemophilus influenzae infection of respiratory mucosa in vitro. Eur Respir J 1998; 11: 86-90.

44 Barnes PJ. Effect of $\beta$-agonists on inflammatory cells. J Allergy Clin Immunol 1999; 104: 10-17.

45 Mak JCW, Nishikawa M, Shirasaki H, Miyayasu K, Barnes PJ. Protective effects of a glucocorticoid on downregulation of pulmonary $\beta_{2}$-adrenergic receptors in vivo. J Clin Invest 1995; 96: 99-106.

46 Disse B. Antimuscarinic treatment for lung diseases from research to clinical practice. Life Sci 2001; 68: 2557-2564.

47 Mundy C, Kirkpatrick P. Tiotropium bromide. Nat Rev Drug Discov 2004; 3: 643-644.

48 Hansel TT, Barnes PJ. Tiotropium bromide: a novel oncedaily anticholinergic bronchodilator for the treatment of COPD. Drugs Today 2002; 38: 585-600.

49 Casaburi R, Mahler DA, Jones PW, et al. A long-term evaluation of once-daily inhaled tiotropium in chronic obstructive pulmonary disease. Eur Respir J 2002; 19: 217-224.

50 Celli B, ZuWallack R, Wang S, Kesten S. Improvement in resting inspiratory capacity and hyperinflation with tiotropium in COPD patients with increased static lung volumes. Chest 2003; 124: 1743-1748.

51 O'Donnell DE, Fluge T, Gerken F, et al. Effects of tiotropium on lung hyperinflation, dyspnoea and exercise tolerance in COPD. Eur Respir J 2004; 23: 832-840.

52 Vincken W, van Noord JA, Greefhorst AP, et al. Improved health outcomes in patients with COPD during 1 yr's treatment with tiotropium. Eur Respir J 2002; 19: 209-216.

53 Donohue JF, Menjoge S, Kesten S. Tolerance to bronchodilating effects of salmeterol in COPD. Respir Med 2003; 97: 1014-1020.

54 Brusasco V, Hodder R, Miravitlles M, Korducki L, Towse L, Kesten S. Health outcomes following treatment for six months with once daily tiotropium compared with twice daily salmeterol in patients with COPD. Thorax 2003; 58: 399-404.

55 Schroeckenstein DC, Bush RK, Chervinsky P, Busse WW. Twelve-hour bronchodilation in asthma with a single aerosol dose of the anticholinergic compound glycopyrrolate. J Allergy Clin Immunol 1988; 82: 115-119.

56 Haddad E-B, Patel H, Keeling JE, Yacoub MH, Barnes PJ, Belvisi MG. Pharmacological characterization of the muscarinic receptor antagonist, glycopyrrolate, in human and guinea-pig airways. $\mathrm{Br} J$ Pharmacol 1999; 127: 413-420.

57 Schelfhout VJ, Joos GF, Ferrer P, Luria X, Pauwels RA. Activity of LAS 34273, a new long-acting anticholinergic antagonist. Am J Respir Crit Care Med 2003; 167: A93.

58 Kawashima K, Fujii T. The lymphocytic cholinergic system and its biological function. Life Sci 2003; 72: 2101-2109.
59 Wessler IK, Kirkpatrick CJ. The non-neuronal cholinergic system: an emerging drug target in the airways. Pulm Pharmacol Ther 2001; 14: 423-434.

60 Wessler I, Kilbinger H, Bittinger F, Unger R, Kirkpatrick CJ. The non-neuronal cholinergic system in humans: expression, function and pathophysiology. Life Sci 2003; 72: 2055-2061.

61 Combivent Inhlation Solution Study Group. Routine nebulized ipratropium and albuterol together are better than either alone in COPD. Chest 1997; 112: 1514-1521.

62 Cazzola M, Marco FD, Santus P, et al. The pharmacodynamic effects of single inhaled doses of formoterol, tiotropium and their combination in patients with COPD. Pulm Pharmacol Ther 2004; 17: 35-39.

63 Tennant RC, Erin EM, Barnes PJ, Hansel TT. Long-acting $\beta_{2}$-adrenoceptor agonists or tiotropium bromide for patients with COPD: is combination therapy justified? Curr Opin Pharmacol 2003; 3: 270-276.

64 Ram FS, Jones PW, Castro AA, et al. Oral theophylline for chronic obstructive pulmonary disease. Cochrane Database Syst Rev 2002; 4: CD003902.

65 ZuWallack RL, Mahler DA, Reilly D, et al. Salmeterol plus theophylline combination therapy in the treatment of COPD. Chest 2001; 119: 1661-1670.

66 Kirsten DK, Wegner RE, Jorres RA, Magnussen H. Effects of theophylline withdrawal in severe chronic obstructive pulmonary disease. Chest 1993; 104: 1101-1107.

67 Chrystyn H, Mulley BA, Peake MD. Dose response relation to oral theophylline in severe chronic obstructive airway disease. BMJ 1988; 297: 1506-1510.

68 Barr RG, Rowe BH, Camargo CA Jr. Methylxanthines for exacerbations of chronic obstructive pulmonary disease: meta-analysis of randomised trials. BMJ 2003; 327: 643.

69 Rabe KF, Magnussen H, Dent G. Theophylline and selective PDE inhibitors as bronchodilators and smooth muscle relaxants. Eur Respir J 1995; 8: 637-642.

70 Barnes PJ. Theophylline: new perspectives on an old drug. Am J Respir Crit Care Med 2003; 167: 813-818.

71 Culpitt SV, de Matos C, Russell RE, Donnelly LE, Rogers DF, Barnes PJ. Effect of theophylline on induced sputum inflammatory indices and neutrophil chemotaxis in COPD. Am J Respir Crit Care Med 2002; 165: 1371-1376.

72 Kobayashi M, Nasuhara Y, Betsuyaku T, et al. Effect of low-dose theophylline on airway inflammation in COPD. Respirology 2004; 9: 249-254.

73 Keatings VM, Jatakanon A, Worsdell YM, Barnes PJ. Effects of inhaled and oral glucocorticoids on inflammatory indices in asthma and COPD. Am J Respir Crit Care Med 1997; 155: 542-548.

74 Culpitt SV, Nightingale JA, Barnes PJ. Effect of high dose inhaled steroid on cells, cytokines and proteases in induced sputum in chronic obstructive pulmonary disease. Am J Respir Crit Care Med 1999; 160: 1635-1639.

75 Loppow D, Schleiss MB, Kanniess F, Taube C, Jorres RA, Magnussen $\mathrm{H}$. In patients with chronic bronchitis a four week trial with inhaled steroids does not attenuate airway inflammation. Respir Med 2001; 95: 115-121.

76 Hansel TT, Tennant RC, Tan AJ, et al. Theophylline: Mechanism of action and use in asthma and chronic obstructive pulmonary disease. Drugs Today (Barc) 2004; 40: 55-69. 
77 Ito K, Lim S, Caramori G, et al. A molecular mechanism of action of theophylline: induction of histone deacetylase activity to decrease inflammatory gene expression. Proc Natl Acad Sci USA 2002; 99: 8921-8926.

78 Cosio BG, Tsaprouni L, Ito K, Jazrawi E, Adcock IM, Barnes PJ. Theophylline restores histone deacetylase activity and steroid responses in COPD macrophages. J Exp Med 2004; 200: 689-695.

79 Ito K, Lim S, Chung KF, Barnes PJ, Adcock IM. Theophylline enhances histone deacetylase activity and restores glucocorticoid function during oxidative stress. Am J Respir Crit Care Med 2002; 165: A625.

80 Niewoehner DE. The role of systemic corticosteroids in acute exacerbation of chronic obstructive pulmonary disease. Am J Respir Med 2002; 1: 243-248.

81 Aaron SD, Vandemheen KL, Hebert P, et al. Outpatient oral prednisone after emergency treatment of chronic obstructive pulmonary disease. N Engl J Med 2003; 348: 2618-2625.

82 Paggiaro PL, Dahle R, Bakran I, Frith L, Hollingworth K, Efthimou J. Multicentre randomised placebo-controlled trial of inhaled fluticasone propionate in patients with chronic obstructive pulmonary disease. Lancet 1998; 351: 773-780.

83 Burge PS, Calverley PMA, Jones PW, Spencer S, Anderson JA, Maslen T. Randomised, double-blind, placebo-controlled study of fluticasone propionate in patients with moderate to severe chronic obstructive pulmonary disease: the ISOLDE trial. BMJ 2000; 320: 1297-1303.

84 Alsaeedi A, Sin DD, McAlister FA. The effects of inhaled corticosteroids in chronic obstructive pulmonary disease: a systematic review of randomized placebo-controlled trials. Am J Med 2002; 113: 59-65.

85 Papi A, Romagnoli M, Baraldo S, et al. Partial reversibility of airflow limitation and increased exhaled $\mathrm{NO}$ and sputum eosinophilia in chronic obstructive pulmonary disease. Am J Respir Crit Care Med 2000; 162: 1773-1777.

86 Fabbri LM, Romagnoli M, Corbetta L, et al. Differences in airway inflammation in patients with fixed airflow obstruction due to asthma or chronic obstructive pulmonary disease. Am J Respir Crit Care Med 2003; 167: 418-424.

87 Hattotuwa KL, Gizycki MJ, Ansari TW, Jeffery PK, Barnes NC. The effects of inhaled fluticasone on airway inflammation in chronic obstructive pulmonary disease: a double-blind, placebo-controlled biopsy study. Am J Respir Crit Care Med 2002; 165: 1592-1596.

88 Culpitt SV, Rogers DF, Shah P, et al. Impaired inhibition by dexamethasone of cytokine release by alveolar macrophages from patients with chronic obstructive pulmonary disease. Am J Respir Crit Care Med 2003; 167: 24-31.

89 Ito K, Lim S, Caramori G, Chung KF, Barnes PJ, Adcock IM. Cigarette smoking reduces histone deacetylase 2 expression, enhances cytokine expression and inhibits glucocorticoid actions in alveolar macrophages. FASEB J 2001; 15: 1100-1102.

90 Barnes PJ, Ito K, Adcock IM. A mechanism of corticosteroid resistance in COPD: inactivation of histone deacetylase. Lancet 2004; 363: 731-733.
91 Ito K, Tomita T, Barnes PJ, Adcock IM. Oxidative stress reduces histone deacetylase (HDAC)2 activity and enhances IL-8 gene expression: role of tyrosine nitration. Biochem Biophys Res Commun 2004; 315: 240-245.

92 Szafranski W, Cukier A, Ramirez A, et al. Efficacy and safety of budesonide/formoterol in the management of chronic obstructive pulmonary disease. Eur Respir J 2003; 21: 74-81.

93 Calverley P, Pauwels R, Vestbo J, et al. Combined salmeterol and fluticasone in the treatment of chronic obstructive pulmonary disease: a randomised controlled trial. Lancet 2003; 361: 449-456.

94 Calverley PM, Boonsawat W, Cseke Z, Zhong N, Peterson S, Olsson H. Maintenance therapy with budesonide and formoterol in chronic obstructive pulmonary disease. Eur Respir J 2003; 22: 912-919.

95 Barnes PJ. Scientific rationale for combination inhalers with a long-acting $\beta 2$-agonists and corticosteroids. Eur Respir J 2002; 19: 182-191.

96 Cazzola M, Dahl R. Inhaled combination therapy with long-acting beta 2-agonists and corticosteroids in stable COPD. Chest 2004; 126: 220-237.

97 Nannini L, Cates C, Lasserson T, Poole P. Combined corticosteroid and long-acting beta-agonist in one inhaler for chronic obstructive pulmonary disease. Cochrane Database Syst Rev 2004; 3: CD003794.

98 Sethi S, Murphy TF. Bacterial infection in chronic obstructive pulmonary disease in 2000: a state-of-the-art review. Clin Microbiol Rev 2001; 14: 336-363.

99 Sethi S, Evans N, Grant BJ, Murphy TF. New strains of bacteria and exacerbations of chronic obstructive pulmonary disease. N Engl J Med 2002; 347: 465-471.

100 Anthonisen NR, Manfreda J, Warren CP, Hershfield ES, Harding GK, Nelson NA. Antibiotic therapy in exacerbations of chronic obstructive pulmonary disease. Ann Intern Med 1987; 106: 196-204.

101 Saint S, Bent S, Vittinghoff E, Grady D. Antibiotics in chronic obstructive pulmonary disease exacerbations. A meta-analysis. JAMA 1995; 273: 957-960.

102 Stockley RA, O'Brien C, Pye A, Hill SL. Relationship of sputum color to nature and outpatient management of acute exacerbations of COPD. Chest 2000; 117: 1638-1645.

103 Simon L, Gauvin F, Amre DK, Saint-Louis P, Lacroix J. Serum procalcitonin and C-reactive protein levels as markers of bacterial infection: a systematic review and meta-analysis. Clin Infect Dis 2004; 39: 206-217.

104 Hill AT, Campbell EJ, Hill SL, Bayley DL, Stockley RA. Association between airway bacterial load and markers of airway inflammation in patients with stable chronic bronchitis. Am J Med 2000; 109: 288-295.

105 Kanner RE, Anthonisen NR, Connett JE. Lower respiratory illnesses promote $\mathrm{FEV}_{1}$ decline in current smokers but not ex-smokers with mild chronic obstructive pulmonary disease: results from the lung health study. Am J Respir Crit Care Med 2001; 164: 358-364.

106 Donaldson GC, Seemungal TA, Bhowmik A, Wedzicha JA. Relationship between exacerbation frequency and lung function decline in chronic obstructive pulmonary disease. Thorax 2002; 57: 847-852.

107 Tamaoki J. The effects of macrolides on inflammatory cells. Chest 2004; 125: Suppl. 2, 41S-50S. 
108 Rubin BK, Henke MO. Immunomodulatory activity and effectiveness of macrolides in chronic airway disease. Chest 2004; 125: Suppl. 2, 70S-78S.

109 Desaki M, Okazaki H, Sunazuka T, Omura S, Yamamoto K, Takizawa H. Molecular mechanisms of anti-inflammatory action of erythromycin in human bronchial epithelial cells: possible role in the signaling pathway that regulates nuclear factor- $\kappa \mathrm{B}$ activation. Antimicrob Agents Chemother 2004; 48: 1581-1585.

110 Kanai K, Asano K, Hisamitsu T, Suzaki H. Suppression of matrix metalloproteinase production from nasal fibroblasts by macrolide antibiotics in vitro. Eur Respir J 2004; 23: $671-678$.

111 Kikuchi T, Hagiwara K, Honda Y, et al. Clarithromycin suppresses lipopolysaccharide-induced interleukin- 8 production by human monocytes through AP-1 and NF- $\kappa$ B transcription factors. J Antimicrob Chemother 2002; 49: 745-755.

112 Keicho N, Kudoh S. Diffuse panbronchiolitis: role of macrolides in therapy. Am J Respir Med 2002; 1: 119-131.

113 Southern KW, Barker PM, Solis A. Macrolide antibiotics for cystic fibrosis. Cochrane Database Syst Rev 2004; 2: CD002203.

114 Bhowmik A, Seemungal TA, Sapsford RJ, Wedzicha JA. Relation of sputum inflammatory markers to symptoms and lung function changes in COPD exacerbations. Thorax 2000; 55: 114-120.

115 Patel IS, Seemungal TA, Wilks M, Lloyd-Owen SJ, Donaldson GC, Wedzicha JA. Relationship between bacterial colonisation and the frequency, character, and severity of COPD exacerbations. Thorax 2002; 57: 759-764.

116 Wilkinson TM, Patel IS, Wilks M, Donaldson GC, Wedzicha JA. Airway bacterial load and $\mathrm{FEV}_{1}$ decline in patients with chronic obstructive pulmonary disease. Am J Respir Crit Care Med 2003; 167: 1090-1095.

117 Continuous or nocturnal oxygen therapy in hypoxemic chronic obstructive lung disease: a clinical trial. Nocturnal Oxygen Therapy Trial Group. Ann Intern Med 1980; 93: 391-398.

118 Long term domiciliary oxygen therapy in chronic hypoxic cor pulmonale complicating chronic bronchitis and emphysema. Report of the Medical Research Council Working Party. Lancet 1981; 1: 681-686.

119 Kessler R, Faller M, Weitzenblum E, et al. "Natural history" of pulmonary hypertension in a series of 131 patients with chronic obstructive lung disease. Am J Respir Crit Care Med 2001; 164: 219-224.

120 Tarpy SP, Celli B. Long-term oxygen therapy. N Engl J Med 1995; 333: 710-714.

121 Wedzicha JA. Domiciliary oxygen therapy services: clinical guidelines and advice for prescribers. Summary of a report of the Royal College of Physicians. J $R$ Coll Physicians Lond 1999; 33: 445-447.

122 Ram FS, Wedzicha JA. Ambulatory oxygen for chronic obstructive pulmonary disease. Cochrane Database Syst Rev 2002; 2: CD000238.

123 Vonbank K, Ziesche R, Higenbottam TW, et al. Controlled prospective randomised trial on the effects on pulmonary haemodynamics of the ambulatory long term use of nitric oxide and oxygen in patients with severe COPD. Thorax 2003; 58: 289-293.
124 Aldashev AA, Sarybaev AS, Sydykov AS, et al. Characterization of high-altitude pulmonary hypertension in the Kyrgyz: association with angiotensin-converting enzyme genotype. Am J Respir Crit Care Med 2002; 166: 1396-1402.

125 Yildiz $\mathrm{P}$, Oflaz $\mathrm{H}$, Cine $\mathrm{N}$, Erginel-Unaltuna $\mathrm{N}$, Erzengin F, Yilmaz V. Gene polymorphisms of endothelial nitric oxide synthase enzyme associated with pulmonary hypertension in patients with COPD. Respir Med 2003; 97: 1282-1288.

126 Schofield CJ, Ratcliffe PJ. Oxygen sensing by HIF hydroxylases. Nat Rev Mol Cell Biol 2004; 5: 343-354.

127 Lacasse Y, Brosseau L, Milne S, et al. Pulmonary rehabilitation for chronic obstructive pulmonary disease. Cochrane Database Syst Rev 2002; 3: CD003793.

128 Griffiths TL, Burr ML, Campbell IA, et al. Results at 1 year of outpatient multidisciplinary pulmonary rehabilitation: a randomised controlled trial. Lancet 2000; 355: 362-368.

129 Troosters T, Gosselink R, Decramer M. Short- and longterm effects of outpatient rehabilitation in patients with chronic obstructive pulmonary disease: a randomized trial. Am J Med 2000; 109: 207-212.

130 Troosters T, Gosselink R, Decramer M. Exercise training in COPD: how to distinguish responders from nonresponders. J Cardiopulm Rehabil 2001; 21: 10-17.

131 Wijkstra PJ, Koeter GH. Outpatient pulmonary rehabilitation. Chest 2002; 121: 2082-2083.

132 Ries AL, Kaplan RM, Myers R, Prewitt LM. Maintenance after pulmonary rehabilitation in chronic lung disease: a randomized trial. Am J Respir Crit Care Med 2003; 167: 880-888.

133 Creutzberg EC, Wouters EF, Mostert R, Pluymers RJ, Schols AM. A role for anabolic steroids in the rehabilitation of patients with COPD? A double-blind, placebocontrolled, randomized trial. Chest 2003; 124: 1733-1742.

134 Casaburi R, Bhasin S, Cosentino L, et al. Effects of testosterone and resistance training in men with chronic obstructive pulmonary disease. Am J Respir Crit Care Med 2004; 170: 870-878.

135 Spruit MA, Gosselink R, Troosters T, et al. Muscle force during an acute exacerbation in hospitalised patients with COPD and its relationship with CXCL8 and IGF-I. Thorax 2003; 58: 752-756.

136 Hawkins P, Johnson LC, Nikoletou D, et al. Proportional assist ventilation as an aid to exercise training in severe chronic obstructive pulmonary disease. Thorax 2002; 57: 853-859.

137 Costes F, Agresti A, Court-Fortune, Roche F, Vergnon JM, Barthelemy JC. Noninvasive ventilation during exercise training improves exercise tolerance in patients with chronic obstructive pulmonary disease. I Cardiopulm Rehabil 2003; 23: 307-313.

138 Agusti AG, Noguera A, Sauleda J, Sala E, Pons J, Busquets $X$. Systemic effects of chronic obstructive pulmonary disease. Eur Respir J 2003; 21: 347-360.

139 Wouters EF, Creutzberg EC, Schols AM. Systemic effects in COPD. Chest 2002; 121: Suppl. 5, 127S-130S.

140 Creutzberg EC, Wouters EF, Mostert R, WelingScheepers CA, Schols AM. Efficacy of nutritional supplementation therapy in depleted patients with chronic 
obstructive pulmonary disease. Nutrition 2003; 19: 120-127.

141 Weisberg J, Wanger J, Olson J, et al. Megestrol acetate stimulates weight gain and ventilation in underweight COPD patients. Chest 2002; 121: 1070-1078.

142 Debigare $\mathrm{R}$, Marquis $\mathrm{K}$, Cote $\mathrm{CH}$, et al. Catabolic/ anabolic balance and muscle wasting in patients with COPD. Chest 2003; 124: 83-89.

143 Agusti AG, Sauleda J, Miralles C, et al. Skeletal muscle apoptosis and weight loss in chronic obstructive pulmonary disease. Am J Respir Crit Care Med 2002; 166: 485-489.

144 Gosker HR, Kubat B, Schaart G, van der Vusse GJ, Wouters EF, Schols AM. Myopathological features in skeletal muscle of patients with chronic obstructive pulmonary disease. Eur Respir J 2003; 22: 280-285.

145 Agusti A, Morla M, Sauleda J, Saus C, Busquets X. NF-кB activation and iNOS upregulation in skeletal muscle of patients with COPD and low body weight. Thorax 2004; 59: 483-487.

146 Bolton CE, Ionescu AA, Shiels KM, et al. Associated loss of fat free mass and bone mineral density in chronic obstructive pulmonary disease. Am J Respir Crit Care Med 2004; 170: 1286-1293.

147 Lightowler JV, Wedzicha JA, Elliott MW, Ram FS. Noninvasive positive pressure ventilation to treat respiratory failure resulting from exacerbations of chronic obstructive pulmonary disease: Cochrane systematic review and meta-analysis. BMJ 2003; 326: 185.

148 Plant PK, Owen JL, Parrott S, Elliott MW. Cost effectiveness of ward based non-invasive ventilation for acute exacerbations of chronic obstructive pulmonary disease: economic analysis of randomised controlled trial. BMJ 2003; 326: 956.

149 Squadrone E, Frigerio P, Fogliati C, et al. Noninvasive vs invasive ventilation in COPD patients with severe acute respiratory failure deemed to require ventilatory assistance. Intensive Care Med 2004; 30: 1303-1310.

150 Simonds AK. Home ventilation. Eur Respir J 2003; 22: Suppl. 47, 38s-46s.

151 Clini E, Sturani C, Rossi A, et al. The Italian multicentre study on noninvasive ventilation in chronic obstructive pulmonary disease patients. Eur Respir J 2002; 20: 529-538.

152 Criner GJ, Cordova FC, Furukawa S, et al. Prospective randomized trial comparing bilateral lung volume reduction surgery to pulmonary rehabilitation in severe chronic obstructive pulmonary disease. Am J Respir Crit Care Med 1999; 160: 2018-2027.

153 Geddes D, Davies M, Koyama H, et al. Effect of lungvolume-reduction surgery in patients with severe emphysema. N Engl J Med 2000; 343: 239-245.

154 Goldstein RS, Todd TR, Guyatt G, et al. Influence of lung volume reduction surgery (LVRS) on health related quality of life in patients with chronic obstructive pulmonary disease. Thorax 2003; 58: 405-410.

155 Fishman A, Martinez F, Naunheim K, et al. A randomized trial comparing lung-volume-reduction surgery with medical therapy for severe emphysema. $N$ Engl J Med 2003; 348: 2059-2073.
156 Toma TP, Hopkinson NS, Hillier J, et al. Bronchoscopic volume reduction with valve implants in patients with severe emphysema. Lancet 2003; 361: 931-933.

157 Snell GI, Holsworth L, Borrill ZL, et al. The potential for bronchoscopic lung volume reduction using bronchial prostheses: a pilot study. Chest 2003; 124: 1073-1080.

158 Yim AP, Hwong TM, Lee TW, et al. Early results of endoscopic lung volume reduction for emphysema. J Thorac Cardiovasc Surg 2004; 127: 1564-1573.

159 Rendina EA, De Giacomo T, Venuta F, et al. Feasibility and safety of the airway bypass procedure for patients with emphysema. J Thorac Cardiovasc Surg 2003; 125: 1294-1299.

160 Yamada M, Kubo H, Kobayashi S, et al. Bone marrowderived progenitor cells are important for lung repair after lipopolysaccharide-induced lung injury. J Immunol 2004; 172: 1266-1272.

161 Neuringer IP, Randell SH. Stem cells and repair of lung injuries. Respir Res 2004; 5: 6.

162 Soderling SH, Beavo JA. Regulation of cAMP and cGMP signaling: new phosphodiesterases and new functions. Curr Opin Cell Biol 2000; 12: 174-179.

163 Houslay MD, Adams DR. PDE4 cAMP phosphodiesterases: modular enzymes that orchestrate signalling cross-talk, desensitization and compartmentalization. Biochem J 2003; 370: 1-18.

164 Sturton G, Fitzgerald M. Phosphodiesterase 4 inhibitors for the treatment of COPD. Chest 2002; 121: Suppl. 1, 192S-196S.

165 Vignola AM. PDE4 inhibitors in COPD - a more selective approach to treatment. Respir Med 2004; 98: 495503.

166 Spond J, Chapman R, Fine J, et al. Comparison of PDE 4 inhibitors, rolipram and SB 207499 (Ariflo), in a rat model of pulmonary neutrophilia. Pulm Pharmacol Ther 2001; 14: 157-164.

167 Bundschuh DS, Eltze M, Barsig J, Wollin L, Hatzelmann A, Beume R. In vivo efficacy in airway disease models of roflumilast, a novel orally active PDE4 inhibitor. J Pharmacol Exp Ther 2001; 297: 280-290.

168 Compton $\mathrm{CH}, \mathrm{Gubb} \mathrm{J}$, Nieman $\mathrm{R}$, et al. Cilomilast, a selective phosphodiesterase- 4 inhibitor for treatment of patients with chronic obstructive pulmonary disease: a randomised, dose-ranging study. Lancet 2001; 358: 265-270.

169 Gamble E, Grootendorst DC, Brightling CE, et al. Antiinflammatory effects of the phosphodiesterase 4 inhibitor cilomilast (Ariflo) in COPD. Am J Respir Crit Care Med 2003; 168: 976-982.

170 Reid P. Roflumilast. Curr Opin Investig Drugs 2002; 3: 1165-1170.

171 Mehats C, Jin SL, Wahlstrom J, Law E, Umetsu DT, Conti M. PDE4D plays a critical role in the control of airway smooth muscle contraction. FASEB J 2003; 17: 1831-1841.

172 Lamontagne S, Meadows E, Luk P, et al. Localization of phosphodiesterase- 4 isoforms in the medulla and nodose ganglion of the squirrel monkey. Brain Res 2001; 920: 84-96. 
173 Robichaud A, Stamatiou PB, Jin SL, et al. Deletion of phosphodiesterase $4 \mathrm{D}$ in mice shortens alpha(2)adrenoceptor-mediated anesthesia, a behavioral correlate of emesis. J Clin Invest 2002; 110: 1045-1052.

174 Manning CD, Burman M, Christensen SB, et al. Suppression of human inflammatory cell function by subtype-selective PDE4 inhibitors correlates with inhibition of PDE4A and PDE4B. Br J Pharmacol 1999; 128: 1393-1398.

175 Jin SL, Conti M. Induction of the cyclic nucleotide phosphodiesterase PDE4B is essential for LPS-activated TNF- $\alpha$ responses. Proc Natl Acad Sci USA 2002; 99: $7628-7633$.

176 Kuss H, Hoefgen N, Johanssen S, Kronbach T, Rundfeldt C. In vivo efficacy in airway disease models of N-(3,5-dichloropyrid-4-yl)-[1-(4-fluorobenzyl)-5-hydroxyindole-3-yl]-glyo xylic acid amide (AWD 12-281), a selective phosphodiesterase 4 inhibitor for inhaled administration. J Pharmacol Exp Ther 2003; 307: 373-385.

177 Soares AC, Souza DG, Pinho V, et al. Impaired host defense to Klebsiella pneumoniae infection in mice treated with the PDE4 inhibitor rolipram. Br J Pharmacol 2003; 140: 855-862.

178 Smith SJ, Brookes-Fazakerley S, Donnelly LE, Barnes PJ, Barnette MS, Giembycz MA. Ubiquitous expression of phosphodiesterase 7A in human proinflammatory and immune cells. Am J Physiol Lung Cell Mol Physiol 2003; 284: L279-L289.

179 Smith SJ, Cieslinski LB, Newton R, et al. Discovery of BRL 50481, a selective inhibitor of phosphodiesterase 7: in vitro studies in human monocytes, lung macrophages and CD8+ T-lymphocytes. Mol Pharmacol 2004; 66: 1679-1689.

180 Barnes PJ. Mediators of chronic obstructive pulmonary disease. Pharm Rev 2004; in press.

181 Montuschi P, Kharitonov SA, Ciabattoni G, Barnes PJ. Exhaled leukotrienes and prostaglandins in COPD. Thorax 2003; 58: 585-588.

182 Montuschi P, Barnes PJ. Exhaled leukotrienes and prostaglandins in asthma. J Allergy Clin Immunol 2002; 109: 615-620.

183 Martin TR, Pistorese BP, Chi EY, Goodman RB, Matthay MA. Effects of leukotriene $B_{4}$ in the human lung. Recruitment of neutrophils into the alveolar spaces without a change in protein permeability. J Clin Invest 1989; 84: 1609-1619.

184 Hill AT, Bayley D, Stockley RA. The interrelationship of sputum inflammatory markers in patients with chronic bronchitis. Am J Respir Crit Care Med 1999; 160: 893-898.

185 Crooks SW, Bayley DL, Hill SL, Stockley RA. Bronchial inflammation in acute bacterial exacerbations of chronic bronchitis: the role of leukotriene $\mathrm{B}_{4}$. Eur Respir J 2000; 15: 274-280.

186 Hill AT, Bayley D, Stockley RA. The interrelationship of sputum inflammatory markers in patients with chronic bronchitis. Am J Respir Crit Care Med 1999; 160: 893-898.

187 Gompertz S, O’Brien C, Bayley DL, Hill SL, Stockley RA. Changes in bronchial inflammation during acute exacerbations of chronic bronchitis. Eur Respir J 2001; 17: 1112-1119.
188 Biernacki WA, Kharitonov SA, Barnes PJ. Increased leukotriene $\mathrm{B}_{4}$ and 8-isoprostane in exhaled breath condensate of patients with exacerbations of COPD. Thorax 2003; 58: 294-298.

189 Woolhouse IS, Bayley DL, Stockley RA. Sputum chemotactic activity in chronic obstructive pulmonary disease: effect of alpha ${ }_{1}$-antitrypsin deficiency and the role of leukotriene $\mathrm{B}_{4}$ and interleukin 8. Thorax 2002; 57: 709-714.

190 Beeh KM, Kornmann O, Buhl R, Culpitt SV, Giembycz MA, Barnes PJ. Neutrophil chemotactic activity of sputum from patients with COPD: role of interleukin 8 and leukotriene $\mathrm{B}_{4}$. Chest 2003; 123: 1240-1247.

191 Luster AD, Tager AM. T-cell trafficking in asthma: lipid mediators grease the way. Nat Rev Immunol 2004; 4: 711-724.

192 Goodarzi K, Goodarzi M, Tager AM, Luster AD, von Andrian UH. Leukotriene B4 and BLT1 control cytotoxic effector $\mathrm{T}$ cell recruitment to inflamed tissues. Nat Immunol 2003; 4: 965-973.

193 Silbaugh SA, Stengel PW, Cockerham SL, et al. Pharmacologic actions of the second generation leukotriene $\mathrm{B}_{4}$ receptor antagonist LY29311: in vivo pulmonary studies. Naunyn Schmiedebergs Arch Pharmacol 2000; 361: 397-404.

194 Gompertz S, Stockley RA. A randomized, placebocontrolled trial of a leukotriene synthesis inhibitor in patients with COPD. Chest 2002; 122: 289-294.

195 Keatings VM, Collins PD, Scott DM, Barnes PJ. Differences in interleukin- 8 and tumor necrosis factor- $\alpha$ in induced sputum from patients with chronic obstructive pulmonary disease or asthma. Am J Respir Crit Care Med 1996; 153: 530-534.

196 Vernooy JH, Kucukaycan M, Jacobs JA, et al. Local and systemic inflammation in patients with chronic obstructive pulmonary disease: soluble tumor necrosis factor receptors are increased in sputum. Am J Respir Crit Care Med 2002; 166: 1218-1224.

197 Pitsiou G, Kyriazis G, Hatzizisi O, Argyropoulou P, Mavrofridis E, Patakas D. Tumor necrosis factor-alpha serum levels, weight loss and tissue oxygenation in chronic obstructive pulmonary disease. Respir Med 2002; 96: 594-598.

198 de Godoy I, Donahoe M, Calhoun WJ, Mancino J, Rogers RM. Elevated TNF- $\alpha$ production by peripheral blood monocytes of weight-losing COPD patients. Am J Respir Crit Care Med 1996; 153: 633-637.

199 Reimold AM. TNF $\alpha$ as therapeutic target: new drugs, more applications. Curr Drug Targets Inflamm Allergy 2002; 1: 377-392.

200 Rabinowitz MH, Andrews RC, Becherer JD, et al. Design of selective and soluble inhibitors of tumor necrosis factor- $\alpha$ converting enzyme (TACE). J Med Chem 2001; 44: 4252-4267.

201 Barnes PJ. Cytokine-directed therapies for the treatment of chronic airway diseases. Cytokine Growth Factor Rev 2003; 14: 511-522.

202 Cohen SB. The use of anakinra, an interleukin-1 receptor antagonist, in the treatment of rheumatoid arthritis. Rheum Dis Clin North Am 2004; 30: 365-380. 
203 Wedzicha JA, Seemungal TA, MacCallum PK, et al. Acute exacerbations of chronic obstructive pulmonary disease are accompanied by elevations of plasma fibrinogen and serum IL-6 levels. Thromb Haemost 2000; 84: 210-215.

204 Bucchioni E, Kharitonov SA, Allegra L, Barnes PJ. High levels of interleukin- 6 in the exhaled breath condensate of patients with COPD. Respir Med 2003; 97: 1299-1302.

205 Seemungal T, Harper-Owen R, Bhowmik A, et al. Respiratory viruses, symptoms, and inflammatory markers in acute exacerbations and stable chronic obstructive pulmonary disease. Am J Respir Crit Care Med 2001; 164: 1618-1623.

206 Nishimoto N, Kishimoto T. Inhibition of IL-6 for the treatment of inflammatory diseases. Curr Opin Pharmacol 2004; 4: 386-391.

207 de Boer WI, van Schadewijk A, Sont JK, et al. Transforming growth factor beta1 and recruitment of macrophages and mast cells in airways in chronic obstructive pulmonary disease. Am J Respir Crit Care Med 1998; 158: 1951-1957.

208 Takizawa H, Tanaka M, Takami K, et al. Increased expression of transforming growth factor-beta1 in small airway epithelium from tobacco smokers and patients with chronic obstructive pulmonary disease (COPD). Am J Respir Crit Care Med 2001; 163: 1476-1483.

209 Dallas SL, Rosser JL, Mundy GR, Bonewald LF. Proteolysis of latent transforming growth factor- $\beta$ (TGF$\beta$ )-binding protein- 1 by osteoclasts. A cellular mechanism for release of TGF- $\beta$ from bone matrix. J Biol Chem 2002; 277: 21352-21360.

210 Mak JC, Rousell J, Haddad EB, Barnes PJ. Transforming growth factor- $\beta 1$ inhibits $\beta_{2}$-adrenoceptor gene transcription. Naunyn Schmiedebergs Arch Pharmacol 2000; 362: 520-525.

211 Ishikawa $T$, Kume $H$, Kondo M, Ito $Y$, Yamaki K, Shimokata K. Inhibitory effects of interferon-gamma on the heterologous desensitization of beta-adrenoceptors by transforming growth factor-beta 1 in tracheal smooth muscle. Clin Exp Allergy 2003; 33: 808-815.

212 Yakymovych I, Engstrom U, Grimsby S, Heldin CH, Souchelnytskyi S. Inhibition of transforming growth factor- $\beta$ signaling by low molecular weight compounds interfering with ATP- or substrate-binding sites of the TGF $\beta$ type I receptor kinase. Biochemistry 2002; 41: 11000-11007.

213 Panina-Bordignon P, D'Ambrosio D. Chemokines and their receptors in asthma and chronic obstructive pulmonary disease. Curr Opin Pulm Med 2003; 9: 104-110.

214 Hay DWP, Sarau HM. Interleukin-8 receptor antagonists in pulmonary diseases. Curr Opin Pharmacol 2001; 1: 242-247.

215 Tanino M, Betsuyaku T, Takeyabu K, et al. Increased levels of interleukin-8 in BAL fluid from smokers susceptible to pulmonary emphysema. Thorax 2002; 57: 405-411.

216 Yamamoto C, Yoneda T, Yoshikawa M, et al. Airway inflammation in COPD assessed by sputum levels of interleukin-8. Chest 1997; 112: 505-510.

217 Yang XD, Corvalan JR, Wang P, Roy CM, Davis CG. Fully human anti-interleukin-8 monoclonal antibodies: potential therapeutics for the treatment of inflammatory disease states. J Leukoc Biol 1999; 66: 401-410.

218 Mahler DA, Huang S, Tabrizi M, Bell GM. Efficacy and safety of a monoclonal antibody recognizing interleukin8 in COPD: a pilot study. Chest 2004; 126: 926-934.

219 Traves SL, Culpitt S, Russell REK, Barnes PJ, Donnelly LE. Elevated levels of the chemokines GRO- $\alpha$ and MCP-1 in sputum samples from COPD patients. Thorax 2002; 57: 590-595.

220 Traves SL, Smith SJ, Barnes PJ, Donnelly LE. Specific CXC but not CC chemokines cause elevated monocyte migration in COPD: a role for CXCR2. J Leukoc Biol 2004; 76: 441-450.

221 Barnes PJ. Macrophages as orchestrators of COPD. J COPD 2004; 1: 59-70.

222 Widdowson KL, Elliott JD, Veber DF, et al. Evaluation of potent and selective small-molecule antagonists for the CXCR2 chemokine receptor. J Med Chem 2004; 47: 1319-1321.

223 Qiu Y, Zhu J, Bandi V, et al. Biopsy neutrophilia, chemokine and receptor gene expression in severe exacerbations of COPD. Am J Respir Crit Care Med 2003; 168: 968-975.

224 Miller AL, Strieter RM, Gruber AD, Ho SB, Lukacs NW. $\mathrm{CXCR} 2$ regulates respiratory syncytial virus-induced airway hyperreactivity and mucus overproduction. J Immunol 2003; 170: 3348-3356.

225 de Boer WI, Sont JK, van Schadewijk A, Stolk J, van Krieken JH, Hiemstra PS. Monocyte chemoattractant protein 1, interleukin 8, and chronic airways inflammation in COPD. J Pathol 2000; 190: 619-626.

226 Grumelli S, Corry DB, Song L-X, et al. An immune basis for lung parenchymal destruction in chronic obstructive pulmonary disease and emphysema. PLoS Med 2004; 1: 75-83.

227 Barnes PJ, Cosio MG. Characterization of T lymphocytes in chronic obstructive pulmonary disease. PLoS Med 2004; 1: 25-27.

228 Saetta M, Mariani M, Panina-Bordignon $\mathrm{P}$, et al. Increased expression of the chemokine receptor CXCR3 and its ligand CXCL10 in peripheral airways of smokers with chronic obstructive pulmonary disease. Am J Respir Crit Care Med 2002; 165: 1404-1409.

229 Montuschi P, Collins JV, Ciabattoni G, et al. Exhaled 8isoprostane as an in vivo biomarker of lung oxidative stress in patients with COPD and healthy smokers. Am J Respir Crit Care Med 2000; 162: 1175-1177.

230 Paredi P, Kharitonov SA, Leak D, Ward S, Cramer D, Barnes PJ. Exhaled ethane, a marker of lipid peroxidation, is elevated in chronic obstructive pulmonary disease. Am J Respir Crit Care Med 2000; 162: 369-373.

231 Rahman I, van Schadewijk AA, Crowther AJ, et al. 4Hydroxy-2-nonenal, a specific lipid peroxidation product, is elevated in lungs of patients with chronic obstructive pulmonary disease. Am J Respir Crit Care Med 2002; 166: 490-495.

232 Macnee W. Oxidants/antioxidants and COPD. Chest 2000; 117: Suppl. 1, 303S-317S.

233 Bowler RP, Barnes PJ, Crapo JD. The role of oxidative stress in chronic obstructive pulmonary disease. J COPD 2004; 2: 255-277. 
234 Poole PJ, Black PN. Oral mucolytic drugs for exacerbations of chronic obstructive pulmonary disease: systematic review. BMJ 2001; 322: 1271-1274.

235 Decramer M, Dekhuijzen PN, Troosters $\mathrm{T}$, et al. The Bronchitis Randomized On NAC Cost-Utility Study (BRONCUS): hypothesis and design. BRONCUS-trial Committee. Eur Respir J 2001; 17: 329-336.

236 Antonicelli F, Brown D, Parmentier M, et al. Regulation of LPS-mediated inflammation in vivo and in vitro by the thiol antioxidant nacystelyn. Am J Physiol Lung Cell Mol Physiol 2004; 286: L1319-L1327.

237 Cuzzocrea S, Thiemermann C, Salvemini D. Potential therapeutic effect of antioxidant therapy in shock and inflammation. Curr Med Chem 2004; 11: 1147-1162.

238 Culpitt SV, Rogers DF, Fenwick PS, et al. Inhibition by red wine extract, resveratrol, of cytokine release by alveolar macrophages in COPD. Thorax 2003; 58: 942-946.

239 Donnelly LE, Newton R, Kennedy GE, et al. Antiinflammatory effects of resveratrol in lung epithelial cells: molecular mechanisms. Am J Physiol Lung Cell Mol Physiol 2004; 287: L744-L783.

240 Ichinose M, Sugiura H, Yamagata S, Koarai A, Shirato K. Increase in reactive nitrogen species production in chronic obstructive pulmonary disease airways. Am J Respir Crit Care Med 2000; 160: 701-706.

241 Hansel TT, Kharitonov SA, Donnelly LE, et al. A selective inhibitor of inducible nitric oxide synthase inhibits exhaled breath nitric oxide in healthy volunteers and asthmatics. FASEB J 2003; 17: 1298-1300.

242 Kharitonov SA, Barnes PJ. Nitric oxide, nitrotyrosine, and nitric oxide modulators in asthma and chronic obstructive pulmonary disease. Curr Allergy Asthma Rep 2003; 3: 121-129.

243 Cohen P. Protein kinases - the major drug targets of the twenty-first century? Nat Rev Drug Discov 2002; 1: 309-315.

244 Di Stefano A, Caramori G, Capelli A, et al. Increased expression of NF- $\kappa \mathrm{B}$ in bronchial biopsies from smokers and patients with COPD. Eur Respir J 2002; 20: 556-563.

245 Caramori G, Romagnoli M, Casolari P, et al. Nuclear localisation of p65 in sputum macrophages but not in sputum neutrophils during COPD exacerbations. Thorax 2003; 58: 348-351.

246 Delhase M, Li N, Karin M. Kinase regulation in inflammatory response. Nature 2000; 406: 367-368.

247 Castro AC, Dang LC, Soucy F, et al. Novel IKK inhibitors: beta-carbolines. Bioorg Med Chem Lett 2003; 13: 2419-2422.

248 Jazrawi E, Cosio BG, Barnes PJ, Adcock IM. Inhibition of IKK2 and JNK differentially regulates GM-CSF and IL-8 release in epithelial cells and alveolar macrophages. Am J Respir Crit Care Med 2003; 167: A798.

249 Nasuhara Y, Adcock IM, Catley M, Barnes PJ, Newton R. Differential IKK activation and $\mathrm{IkB} \alpha$ degradation by interleukin-1 $\beta$ and tumor necrosis factor- $\alpha$ in human U937 monocytic cells: evidence for additional regulatory

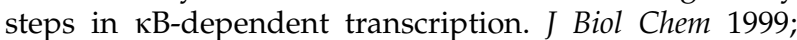
274: 19965-19972.

250 Johnson GL, Lapadat R. Mitogen-activated protein kinase pathways mediated by ERK, JNK, and p38 protein kinases. Science 2002; 298: 1911-1912.
251 Meja KK, Seldon PM, Nasuhara Y, et al. p38 MAP kinase and MKK-1 co-operate in the generation of GM-CSF from LPS-stimulated human monocytes by an NF- $\kappa B-i n d e p e n-$ dent mechanism. Br J Pharmacol 2000; 131: 1143-1153.

252 Kumar S, Boehm J, Lee JC. p38 MAP kinases: key signalling molecules as therapeutic targets for inflammatory diseases. Nat Rev Drug Discov 2003; 2: 717-726.

253 Underwood DC, Osborn RR, Bochnowicz S, et al. SB 239063, a p38 MAPK inhibitor, reduces neutrophilia, inflammatory cytokines, MMP-9, and fibrosis in lung. Am J Physiol Lung Cell Mol Physiol 2000; 279: L895-L902.

254 Sasaki T, Irie-Sasaki J, Jones RG, et al. Function of PI3K $\gamma$ in thymocyte development, $\mathrm{T}$ cell activation, and neutrophil migration. Science 2000; 287: 1040-1046.

255 Ward S, Sotsios Y, Dowden J, Bruce I, Finan P Therapeutic potential of phosphoinositide 3-kinase inhibitors. Chem Biol 2003; 10: 207-213.

256 Jiang C, Ting AT, Seed B. PPAR- $\gamma$ agonists inhibit production of monocyte inflammatory cytokines. Nature 1998; 391: 82-86.

257 Patel HJ, Belvisi MG, Bishop-Bailey D, Yacoub $\mathrm{MH}$, Mitchell JA. Activation of peroxisome proliferator-activated receptors in human airway smooth muscle cells has a superior anti-inflammatory profile to corticosteroids: relevance for chronic obstructive pulmonary disease therapy. J Immunol 2003; 170: 2663-2669.

258 Harris SG, Phipps RP. Induction of apoptosis in mouse T cells upon peroxisome proliferator-activated receptor gamma (PPAR- $\gamma$ ) binding. Adv Exp Med Biol 2002; 507: 421-425.

259 Stockley RA. Neutrophils and protease/antiprotease imbalance. Am J Respir Crit Care Med 1999; 160: S49-S52.

260 Shapiro SD, Senior RM. Matrix metalloproteinases. Matrix degradation and more. Am J Respir Cell Mol Biol 1999; 20: 1100-1102.

261 Sandhaus RA. alpha1-Antitrypsin deficiency. 6: new and emerging treatments for $\alpha_{1}$-antitrypsin deficiency. Thorax 2004; 59: 904-909.

262 Luisetti M, Travis J. Bioengineering: $\alpha_{1}$-proteinase inhibitor site-specific mutagenesis. The prospect for improving the inhibitor. Chest 1996; 110: Suppl. 6, 278S-283S.

263 Stecenko AA, Brigham KL. Gene therapy progress and prospects: $\alpha 1$ antitrypsin. Gene Ther 2003; 10: 95-99.

264 Dirksen A, Dijkman JH, Madsen F, et al. A randomized clinical trial of $\alpha_{1}$-antitrypsin augmentation therapy. Am J Respir Crit Care Med 1999; 160: 1468-1472.

265 Moraes TJ, Chow CW, Downey GP. Proteases and lung injury. Crit Care Med 2003; 31: Suppl. 4, S189-S194.

266 Luisetti M, Sturani C, Sella D, et al. MR889, a neutrophil elastase inhibitor, in patients with chronic obstructive pulmonary disease: a double-blind, randomized, placebo-controlled clinical trial. Eur Respir J 1996; 9: 1482-1486.

267 Fujie K, Shinguh Y, Yamazaki A, Hatanaka H, Okamoto M, Okuhara M. Inhibition of elastase-induced acute inflammation and pulmonary emphysema in hamsters by a novel neutrophil elastase inhibitor FR901277. Inflamm Res 1999; 48: 160-167.

268 Burnett D, Abrahamson M, Devalia JL, Sapsford RJ, Davies RJ, Buttle DJ. Synthesis and secretion of procathepsin $\mathrm{B}$ and cystatin $\mathrm{C}$ by human bronchial epithelial 
cells in vitro: modulation of cathepsin B activity by neutrophil elastase. Arch Biochem Biophys 1995; 317: 305-310.

269 Ferry G, Lonchampt M, Pennel L, de Nanteuil G, Canet E, Tucker GC. Activation of MMP-9 by neutrophil elastase in an in vivo model of acute lung injury. FEBS Lett 1997; 402: 111-115.

270 Zhu YK, Liu XD, Skold CM, et al. Synergistic neutrophil elastase-cytokine interaction degrades collagen in three-dimensional culture. Am J Physiol Lung Cell Mol Physiol 2001; 281: L868-L878.

271 Russell RE, Thorley A, Culpitt SV, et al. Alveolar macrophage-mediated elastolysis: roles of matrix metalloproteinases, cysteine, and serine proteases. Am J Physiol Lung Cell Mol Physiol 2002; 283: L867-L873.

272 Leung-Toung R, Li W, Tam TF, Karimian K. Thioldependent enzymes and their inhibitors: a review. Curr Med Chem 2002; 9: 979-1002.

273 Belvisi MG, Bottomley KM. The role of matrix metalloproteinases (MMPs) in the pathophysiology of chronic obstructive pulmonary disease (COPD): a therapeutic role for inhibitors of MMPs? Inflamm Res 2003; 52: 95-100.

274 Matter H, Schudok M. Recent advances in the design of matrix metalloprotease inhibitors. Curr Opin Drug Discov Devel 2004; 7: 513-535.

275 Russell RE, Culpitt SV, DeMatos C, et al. Release and activity of matrix metalloproteinase- 9 and tissue inhibitor of metalloproteinase- 1 by alveolar macrophages from patients with chronic obstructive pulmonary disease. Am J Respir Cell Mol Biol 2002; 26: 602-609.

276 Vestbo J. Epidemiological studies in mucus hypersecretion. Novartis Found Symp 2002; 248: 3-12.

277 Barnes PJ. Current and future therapies for airway mucus hypersecretion. Novartis Found Symp 2002; 248: 237-249.

278 Nadel JA, Burgel PR. The role of epidermal growth factor in mucus production. Curr Opin Pharmacol 2001; 1: 254-258.

279 Zhou Y, Shapiro M, Dong Q, et al. A calcium-activated chloride channel blocker inhibits goblet cell metaplasia and mucus overproduction. Novartis Found Symp 2002; 248: 150-165.

280 Knight D. Talniflumate (Genaera). Curr Opin Investig Drugs 2004; 5: 557-562.

281 Rogers DF. Pharmacological regulation of the neuronal control of airway mucus secretion. Curr Opin Pharmacol 2002; 2: 249-255.

282 Barbera JA, Peinado VI, Santos S. Pulmonary hypertension in chronic obstructive pulmonary disease. Eur Respir J 2003; 21: 892-905.
283 Peinado VI, Barbera JA, Abate P, et al. Inflammatory reaction in pulmonary muscular arteries of patients with mild chronic obstructive pulmonary disease. Am J Respir Crit Care Med 1999; 159: 1605-1611.

284 Humbert M, Sitbon O, Simonneau G. Treatment of pulmonary arterial hypertension. N Engl J Med 2004; 351: 1425-1436.

285 Giaid A, Yanagisawa M, Langleben D, Michel RP, Levy R, Shennib M, et al. Expression of endothelin-1 in the lungs of patients with pulmonary hypertension. $N$ Engl J Med 1993; 328: 1732-1739.

286 Channick RN, Sitbon O, Barst RJ, Manes A, Rubin LJ. Endothelin receptor antagonists in pulmonary arterial hypertension. J Am Coll Cardiol 2004; 43: Suppl. 12, 62S-67S.

287 Davie N, Haleen SJ, Upton PD, et al. ETA and ETB receptors modulate the proliferation of human pulmonary artery smooth muscle cells. Am J Respir Crit Care Med 2002; 165: 398-405.

288 Galie N, Manes A, Branzi A. Prostanoids for pulmonary arterial hypertension. Am J Respir Med 2003; 2: 123-137.

289 Sebkhi A, Strange JW, Phillips SC, Wharton J, Wilkins MR. Phosphodiesterase type 5 as a target for the treatment of hypoxia-induced pulmonary hypertension. Circulation 2003; 107: 3230-3235.

290 Sandford AJ, Silverman EK. Chronic obstructive pulmonary disease. 1: Susceptibility factors for COPD the genotype-environment interaction. Thorax 2002; 57: 736-741.

291 Hackett NR, Heguy A, Harvey BG, et al. Variability of antioxidant-related gene expression in the airway epithelium of cigarette smokers. Am J Respir Cell Mol Biol 2003; 29: 331-343.

292 Malcolm KC, Arndt PG, Manos EJ, Jones DA, Worthen GS. Microarray analysis of lipopolysaccharidetreated human neutrophils. Am J Physiol Lung Cell Mol Physiol 2003; 284: L663-L670.

293 Waldburg N, Kahne T, Reisenauer A, Rocken C, Welte T, Buhling F. Clinical proteomics in lung diseases. Pathol Res Pract 2004; 200: 147-154.

294 Kharitonov SA, Barnes PJ. Exhaled markers of pulmonary disease. Am J Respir Crit Care Med 2001; 163: 1693-1772.

295 Dowson LJ, Guest PJ, Stockley RA. Longitudinal changes in physiological, radiological, and health status measurements in $\alpha_{1}$-antitrypsin deficiency and factors associated with decline. Am J Respir Crit Care Med 2001; 164: 1805-1809. 